\title{
İlkokul Yöneticilerinin Mizah Kullanma Tarzları ile Öğretmenlerin Stres Yaşama Düzeyleri Arasındaki İlişki ve Bazı Değişkenlere Göre İncelenmesi*
}

\section{Examining Relationship Between Primary School Administrators' Humor Style and Teachers' Percieved Stress Level According to Some Variables}

\author{
Ümmü Gülsüm DİNÇ ${ }^{1}$
}

Makalenin geliş tarihi: 16.01 .2018

\author{
Necati CEMALOĞLU
}

Kabul ediliş tarihi: 29.05 .2018

\section{$\ddot{O} \mathbf{z}$}

Araştırmanın amacı, ilkokullarda çalışan öğretmenlerin algılarına göre, okul yöneticilerinin kullandıkları mizah tarzları ile öğretmenlerin stres yaşama düzeyleri arasındaki ilişsiyi saptamak ve bazı değişkenlere göre incelemektir. Araştırma, ilişkisel tarama modelindedir. Araştırmanın evrenini Ankara ili Çankaya ilçesindeki farklı sosyo-ekonomik seviyelerde (düşük, orta, yüksek) bulunan 75 resmi ilkokulda çalışan 1636 öğretmen oluşturmaktadır. Örneklem için, belirlenen ilçede bulunan 30 okulda görev yapan 300 öğretmene ulaşı1mış, elde edilen veriler analizlerde kullanılmıştır. Veri toplama aracı olarak, Mizah Davranışları Ölçeği ve Algılanan Stres Ölçeği kullanılmıştır. Verilerin analizinde parametrik testler; n, aritmetik ortalama, pearson momentler çarpımı korelasyon katsayısı, regresyon analizi, independent sample t-testi ve tek yönlü varyans analizi kullanılmıştır. Araştırma sonucunda; okul yöneticilerinin çok fazla mizah kullanmadıkları, daha çok onaylayıcı mizahı tarzını tercih ettikleri; okul yöneticilerinin kullandığı alaycı ve reddedici mizah tarzının öğretmenlerde strese neden olduğu; kadın öğretmenlere göre okul yöneticilerinin daha çok alaycı mizahı, erkek öğretmenlere göre ise okul yöneticilerinin daha fazla üretici sosyal mizahı tercih ettikleri; öğretmenlerin sosyo-ekonomik düzeylerinin okul yöneticilerinin mizah tarzları ve stres arasında bir rolü olmadığı; mesleği bırakmayı düşünen öğretmenlerin, okul yöneticilerinin daha fazla alaycı ve reddedici mizahı kullandıklarını ileri sürdükleri ve stres yaşadıkları bulgularına ulaşılmışır.

Anahtar Sözcükler: Mizah, mizah tarzları, stres, okul yöneticisi, öğretmen.

\begin{abstract}
The aim of study is to determine the relationship between primary school administrators' humor styles and teachers' percieved stress level according to some variables. This research is conducted with relational screening model. The population of the research includes 1636 teachers who work at 75 state primary schools at three different socio-economic levels of Çankaya district of Ankara. 300 teachers who work at 30 different schools located in the selected district have been reached. As the data collection tool, Humor Behavior Scale
\end{abstract}

\footnotetext{
*Bu çalışma danışmanlığ Prof. Dr. Necati CEMALOĞLU tarafından yürütülen yüksek lisans tezinden türetilmiştir. 27. ICES-UEBK Uluslararası Eğitim Bilimleri Kongresinde de bildiri olarak sunulmuştur.

${ }^{1}$ Gazi Üniversitesi, Eğitim Fakültesi, Eğitim Bilimleri Bölümü, Eğitim Yönetimi Anabilim Dalı, ummu_gul@ yahoo.com. ${ }^{2}$ Prof. Dr., Gazi Üniversitesi, Eğitim Fakültesi, Eğitim Bilimleri Bölümü, Eğitim Yönetimi Anabilim Dalı, necem@gazi.edu.tr.
} 
and Percieved Stress Scale have been utilized. For the analysis of the data, parametric tests; n, arithmetic mean, pearson product-moment correlation coefficient, regression analysis, independent samples t-test and one-way anova have been used. The findings of the research show that school administrators exhibit low-level of humor and they mostly prefer approving humor; their cynical and rejectionist humor causes distress among teachers; they opt for a cynical humor according to the perceptions of the female teachers, while male teachers are in the opinion that they mostly prefer producing-social humor; they opt for a cynical humor. Moreover, it has been concluded from the findings that the socio-economic level of the teachers has no effect on the administrators' humor style and distress.

Keywords: Humor, humor styles, stress, school administor, teacher.

\section{GİRIŞ}

Öğretmenlerin stres yaşamalarında etkili olan değişkenlerin birbiriyle ilişkileri ve sonuçlarına göre, okul yöneticilerinin yönetme davranışları ile öğretmenlerin stres yaşamaları arasında anlamlı bir fark gözlemlenmiştir. Yöneticilerin etkili bir öğretim lideri olabilmeleri, çalışanların verimliliğini arttırmak için etkili bir iletişim metodu kullanmaları ve olumlu bir okul iklimi tesis etmelerinin okul yöneticilerinin en önemli görevlerinden biri olduğu ileri sürülebilir. Hallinger ve Murphy (1986), okul yöneticilerinin yönetim tarzlarını saptamak amacıyla yaptıkları araştırmada okullarda sağlıklı bir iletişim kurulmasında, medeni bir disiplin anlayışının izlenmesinde, öğretimin örgütlenmesinde, öğrenci tavırlarını düzenleme ve akademik başarıya katkı sağlamada, vizyonun belirlenmesinde ve güç paylaşımında etkili bir yönetim tarzı sergileyen müdürlerin rolünün olduğunu ortaya çıkarmışlardır. Sağlıklı bir iklim oluşturacak şekilde olumlu mizah kullanımının okullarda esnekliği sağladığı, iletişimi kolaylaştırdığı, 1lımlı bir ortam yarattığı, farklı bakış açıları ve vizyon kazandırdığı ifade edilmektedir (Ziegler, Boardman ve Thomas, 1985). Thorson ve Powell (1991), mizah duygusunun, mizahın üretiminin, mizahın onaylanmasının ve ortak hedeflere ulaşmak için olumsuz durumlarla bir baş etme yöntemi olarak mizahın kullanılmasının önemini vurgulamaktadır.

Günümüzde mizahın ve mizahı incelemenin gereksiz olduğu düşünüldüğünden, bunun için ayrılan zaman da boşa tüketilen zaman olarak değerlendirilmektedir. Mizah ve gülme eylemi ciddiyetsiz olarak nitelendirildiği için bu kavramları inceleme veya çözümlemeye yönelik yeteri kadar çalışma yapılmamakta ve mizahı araştırma girişiminde bulunanlara da zamanı boşa harcayan kişi gözüyle bakılmaktadır (Hurren, 2001). Oysaki mizah ve gülmenin yaşantımıza olan etkileri düşünüldüğünde bu konunun daha çok araştırılmaya değer olduğu görülecektir. Mizah araşttrılmak için oldukça önemli bir alandır ve bir bilim dalı olacak özellikte bir kavramdır (Özünlü, 1999, s.12). Lowe (1986), mizah kullanılarak örgüt içi çatışmaların kolaylıkla manipüle edilip azaltılabileceğini ve bir örgütün normlarının yerleşmesinde mizah kullanımının katkısı olduğunu ifade etmiştir. Hampes (1992) ise mizahın insan ilişkilerini zenginleştirici bir etkisi olduğunu ifade etmiştir. 
Ülkemizde örgüt liderlerinin iş hayatında mizah yeteneklerini kullanması gerekliliğine dair yapılan araştırmalar sınırlıdır ve çoğu örgüt yönetimde mizahın olması gerektiği fikrine mesafeli durmaktadır. Ancak; yapılan araştırmalar iş görenlerin performansında, verimliliğinde, sahip oldukları iş doyumunda, üretkenlikte ve liderlikte mizahın etkisinden bahsetmektedir (Spurgeon, 1998, s. 9).

İnsana özgü toplumsal bir olgu olan mizah kavramı, çeşitli alanlardan birçok araştırmacı, yazar ve düşünür tarafindan irdelenmiş; ancak buna rağmen mizahın tanımı konusunda henüz hemfikir olunamamıştır. Sosyolojik fonksiyonları düşünüldüğünde mizah, yakın geçmişimize kadar ciddiye alınmamış ve kökeni çok eskiye dayanmasına rağmen araştırma konusu olarak pek değer görmemiştir. 1980'li yılların başına kadar mizah ciddi bir araştırma konusu olamamıştır. Bu nedenle yapılanların çoğu yakın geçmişli çalışmalardır (Aslan, 2006, s. 2). Mizah özellikle 1980'li yıllardan itibaren farklı iş kollarından birçok yönetici ve danışmanın dikkatini çekmiş ve bunun sonrasında komik, ciddiye alınmayan bir kavram olmaktan çıkartılıp araştırılmaya başlanmıştır (Spurgeon, 1998, s. 8 ). Mizah konusunu araştıranlar, mizahı daha iyi algılayabilmek için mizahin güçlü ve pozitif etkileri üzerinde daha ciddi çalışmalar yapılması gerektiği konusunda aynı fikirdedir (Recepoğlu, 2008). Tarihsel süreç boyunca mizahın farklı anlamlarda kavramsallaştırıldığı ve çok farklı içerikle ilişkilendirildiği görülmektedir (Martin, 1998, s. 23). Mizah, 19. yüzyılın ortalarından itibaren oldukça önemsenen bir kavram haline gelmiş ve 1870'li yıllarda kişilerde aranılan bir özelik olmuştur. Bu dönemde bir insanda mizah duygusunun varlığından bahsetmek, onun kişiliği üzerine olumlu bir atıfta bulunulduğu anlamını taşımaktaydı. Diğer taraftan, bir insanı mizah anlayışından yoksun olarak nitelemek ise onun hakkında söylenebilecek en kötü özelliklerden biri olarak düşünülüyor ve kimse kendisinde mizahi duygunun olmadığını açıkça kabul etmiyordu (Martin, 2007). Son y1llarda mizah kavramı espri, ironi, kinâye ve hiciv gibi tanımlardan farklı görülerek, insanın eksikliklerini, kusurlarını yermek yerine, sevgi ve hoşgörüyü yüceltip hiçbir çıkar gözetmeden sergilenen bir eğlenme sanatı olarak tanımlanmaktadır (Martin, 1998). 21. yüzyılda mizah kavramı genellikle insanlarda pozitif bir anlam ifade etmekte ve büyük çoğunlukla tebessüme sebep olmaktadır.

Yapılan araştırmalar mizahın depresyona karşı direnç geliştirdiğini, bireyin ruh halini dengelediği ve morali yükselttiğini (du Pre, 1998) göstermiştir. İnsanlar arasında etkili bir iletişim kurulmasında önemli bir rol alan mizahın stresli bir durumu değiştirmek veya tamamen ortadan kaldırılmak için kullanılması mümkündür. Mizah, olası bir çatışma ve gerilimi azaltmak ve olumlu duygu durumlarını çoğaltmak amacıyla kullanıldığında strese karşı bir baş etme yöntemi olarak etkili olabilir (Yerlikaya, 2007, s. 22). Martin (2007), günlük yaşantımızda gerçekleşen mizahı, üç ana bölüme ayrılabileceğimizi ifade etmektedir. Bunlardan birincisi; akla gelen komik anılar, fikralar ve esprilerin etrafımızdakilere aktarılması, ikincisi; kişilerarası iletişim esnasında kendiliğinden gelişen ve kasıtlı paylaşılan mizahi söylemler ve son olarak; kasıtlı ya da istendik gerçekleşmeyen mizahtır. 
Bununla birlikte, mizah süreci dört bileşenden oluşmaktadır: sosyal bağlam, kognitif süreç, duygusal tepki ve gülme eylemi.

Mizah Tarzları

Mizah denildiğinde akla gelen başka bir kavram ise mizah tarzıdır. Oldukça kapsamlı bir olgu (Martin, Puhlik-Doris, Larsen, Gray ve Weir, 2003) olan mizah; bilişsel yetenek, estetik yanıt, alışılagelmiş bir davranış kalıbı, mizaç özelliği, başa çıkma metodu veya savunma mekanizması olarak algılanabilir. Mizah tarzları, kişilerarası iletişimin ifade edilişs şeklidir (Yip ve Martin, 2006). Bireysel farklılıklar, duygu durumları ve içinde bulunulan ruh hali mizahın kullanılmasında farklılıklar doğurduğu için mizahı çok boyutlu incelemek gerekir (Thorson ve Powell, 1993). Bu nedenle, mizahın günlük yaşamda kullanımına bağlı farklı tarzlar ortaya çıkarılmıştır. Babad (1974), mizahı dört farklı boyutta kavramsallaştırmıştır;

- Onaylayıc1 (appreciator) mizah,

- $\quad$ Üretici sosyal (producer) mizah,

- $\quad$ Aktarıcı (reproducer) mizah,

- $\quad$ Mizahi olmayan (nonhumorous) tarz olmak üzere gruplandırılmıştır.

Martin vd., (2003), "katılımcı mizah, kendini geliştirici mizah, saldırgan mizah ve kendini yıkıcı mizah" olmak üzere mizahı dört ayrı tarzda boyutlandırmışlardır. Sosyal ilişkilerde mizah kullanımını, uyumlu/olumlu veya uyumsuz/olumsuz, içsel veya bireylerarası olarak gruplandırmışlardır. Katılımcı ve kendini geliştirici mizah tarzının sosyal etkileşimde faydalı oluğunu savunurken, saldırgan ve kendini yıkıcı mizah tarzının ise zararlı olabileceğini ifade etmişlerdir. Cemaloğlu, Recepoğlu, Şahin, Daşçı ve Köktürk (2012) mizahı; "alaycı, üretici-sosyal, onaylayıcı, reddedici ve mizahi olmayan tarz" olmak üzere beş boyutta ele almaktadır. Bu boyutlardan "alaycı mizah" "saldırgan mizah" tarzı ile benzerlik gösterirken, "onaylayıcı mizah" da "katılımcı mizah" tarzı ile birbirine benzer özellikler sergilemektedir.

\section{Alaycı mizah (Cynical humor)}

Alaycı mizahta birey, kendini üstün görerek başkalarını aşağılamak, incitmek, üzmek ve ilişkilere sınır koymak amacıyla bu türü kullanılır. Bu tarzı benimseyen okul yöneticileri, mizah yoluyla öğretmen, öğrenci, veli ve diğer personeller ile alay etmektedir. Aklına gelen her komik şeyi düşünmeden söyleme eğilimdedirler. Karşılarındakilerini toplum içinde hiç tereddüt etmeden küçük düşürmeye, ezmeye ve karşısındakiler üzerinde baskı oluşturmaya çalışır. Mizahi yönü olduğunu fark ettiği kişilere saldırmak ve onlara hadlerini bildirmek için bir araç olarak kullanır. Okuldaki iletişimi ve etkileşimi geliştirmek yerine etrafindakilere saldırma ya da sınır koymayı yeğlerler. Kişilerin hatalarını kaydedip firsatını bulduğunda bu hatalarla dalga geçerler. Alaycı mizah tarzı bu yönüyle olumsuz bir mizah tarzı olarak görülmektedir (Cemaloğlu, 2017). 


\section{Üretici-sosyal mizah (Productive-social humor)}

Bu mizah tarzında kişilerarası iletişimi kolaylaştırmak ve geliştirmek için mizah üretilir ve paylaşılır. Başkalarını eğlendirmek amacıyla şakalar, espriler yapılır. Üretici-sosyal mizah tarzına yakın okul yöneticileri, bulundukları ortamda sıklıkla fikralar anlatır. F1kraları aklında tutma ve anlatma kapasitesi oldukça iyidir. Başkalarının yaşadığı gülünç tecrübeleri paylaşır ve bunlara güler. Yaşadığı olaylara genellikle fikra ya da espri ile karşılık verirler. İnsanları güldürmekten büyük keyif alır, geçmişte yaşadığı deneyimleri acı ve zor da olsa bunları aktarırken komik bir dil kullanır. F1kraları anlatırken genellikle kahramanları, yer ve zamanı değiştirerek farklı durumlara uyarlamayı severler. Üretici-sosyal mizah tarzını benimseyenlerdeki en yaygın davranış, "yeni bir fikra öğrendim, haydi gelin size anlatayım” şeklindedir. Bu tarz mizah, mizaha karşı olumlu bir tutum sergilemeyi ifade eder (Cemaloğlu, 2017).

\section{Onaylayıcı mizah (Approving humor)}

Üçüncü boyuttaki onaylayıcı mizah ise, olaylara mizahi bir bakış açısıyla bakmayı ifade eder. $\mathrm{Bu}$ tarz mizahı benimseyen okul yöneticileri, mizah yapan kişilere sempatiyle yaklaşırlar, kendilerine espri yapıldığında veya espri ile tepkide bulunulduğunda mutlu olurlar. Bu tür tepkileri destekleyip başkaları şaka yapınca olumlu bir tepki ile karşılık verirler. Mizahı onaylayarak mizah kullanılmasına yönelik teşvik edici bir tavır içindedirler. Onaylayıcı mizah tarzı, mizaha karşı olumlu bir tavır sergilemeyi hedefler (Cemaloğlu, 2017).

\section{Reddedici mizah (Rejectionist humor)}

Reddedici mizah, mizah içeren her şeyi geri çeviren bir tarzdır. Bu tarzın davranışlarına yakın olan okul yöneticileri, okullarında mizah yapan kişileri güvenilir bulmaz. Mizahı kullananları çocuksu, olgunlaşmamış, mesleğin değer ve ciddiyetini kavrayamamış çalışanlar olarak algılar. Öğretmenlik mesleğinin değerleri ile mizah davranışlarını bağdaştıramaz. Kendisine mizahi bir tutumla yaklaşanlara olumlu bir gözle bakmaz. Yapılan esprilere şüphe duyarak bakarken, söylenenlere farklı anlamlar yükleme eğilimindedirler. Hatta zaman zaman paranoyakça tavırlar sergileyebilir. Reddedici mizaha sahip kişilerde en sık görülen davranış mizahı yapanları sert bir üslup ile uyarmasıdır. Olumsuz kabul edilen bir mizah tarzıdır (Cemaloğlu, 2017).

\section{Mizahi olmayan (Non-humorous style)}

Bu tarzı benimseyen okul yöneticileri mizahı nadiren kullanır ya da hiç kullanmazlar. Fazla gülmezler, oldukça ciddidirler. Her şeyi ciddiye alırlar. Nadiren mizah yaptıklarında karşılarındakiler yaptıklarının mizah olup olmadığını anlayamazlar. Esnek olmadıkları ve iletişimi kuvvetlendirici araçları kullanmayı tercih etmedikleri için okullarda çıkan sorunlar içinden çıkılmaz bir hal alabilir (Cemaloğlu, 2017).

Yönetim ve Mizah

Kişilerarası iletişimi kuvvetlendirici fonksiyonu düşünüldüğünde, yönetimde mizahın sergilenmesinin önemi göz ardı edilmemelidir. Mizahın yönetime uygulanmasını konu alan çok fazla 
ampirik çalışmanın yapılmadığı gibi birçok örgüt mizah ile iş yaşamının uyumlu olmadığı fikrine sahiptir. Ancak, araştırmalar gösteriyor ki; iş doyumunda, üretkenlikte, performansta ve liderlikte mizahın etkisi vardır (Spurgeon, 1998, s.9). Napier ve Gershenfeld (1981), örgütte mizahı kullanan mizahı kabul eden liderlerin çalışanlarının kendilerini gerçekleştirmesine yardımcı olmasını sağlarken, aynı zamanda örgütün önceden belirlenmiş amaçlarına ulaşılmasında önemli bir katkısı olduğunu ifade etmiştir. Ayrıca, mizahın etkili bir biçimde kullanımı, yönetici ve yardımcılarının kişilerarası ilişkilerini olumlu yönde güçlendirmektedir (Özdemir, 2002). Sala (2003), mizahın yöneticiler için gerekli bir beceri olduğunu söyleyerek mizahın iletişimdeki rolünü vurgulamıştır. Okullar eğitim ve öğretimin gerçekleştirildiği örgütler olarak düşünüldüğünde, öğretim lideri olarak müdürlerin de mizahı kullanmaları etkili bir liderlik sergilemelerine yardımcı olabilir. Philbrick (1989), okul müdürlerinin mizah tarzları ile ilgili araştırmalar yapan ilk kişi olduğu bilinmektedir. Philbrick, öğretim lideri olan müdürleri konu alan araştırmasını Babad'ın (1974) mizahı dört boyutta kavramsallaştırdığı çalışması üzerine yoğunlaştırmıştır. Ziegler ve Boardman'a (1986) göre mizah müdürler için yararlı bir araçtır. Okullarda çalışan diğer herkesten daha fazla yetki ve sorumluluğa sahip olduklarından, okul iklimi üzerinde en fazla etkiye sahip kişilerdir. Okul müdürlerinin mizahi yeteneklerini geliştirmeleri gerekmektedir. Williams (1994), çalışmasında mizahı takdir eden ve paylaşan okul müdürlerinin okullarda olumlu bir iklim tesis ettiğini ifade etmiştir. Esprili olmayan, her şeye ciddi bir tavırla yaklaşan müdürlerin ise, sağlıksız bir okul ikliminin oluşumunda etkisi olduğunu söyleyip okul müdürlerinin mizah tarzları ve okul iklimi arasında bağ olduğunu vurgulamıştır. Mizahın öğretmen motivasyonu, verimliliği ve iş doyumunu arttırırken, öğretmenlerin algıladıkları stresi ve kaosu azaltmakta etkili bir öğe olabileceği ifade edilmektedir (Özdemir ve Recepoğlu, 2010). Williams ve Clouse (1991) mizahın, okul müdürü, öğretmenler ve veliler arasındaki uyuşmazlıkları çözmede okul yöneticilerine yardım sağlayacak önemli bir araç olduğunu ileri sürmektedir. Barth (1990, s. 515), bir meslek olarak okul müdürlüğünde en eksik olan şeyin mizah olduğunu ve okul müdürlerinin bu becerilerini geliştirip daha iyi kullanmaları gerektiğini söylemiştir. Aynı zamanda, mizahın karar alma ve ilişki kurma becerisini geliştirdiğini, verimliliği arttırdığını ve grup birlikteliğini sağladığını saptamışlardır. Yönetimde karşılaşılması olası sorunların önlenmesinde, çözümünde, çatışmayı azaltmada, çalışanların motivasyonunu arttırmada, ilişkileri geliştirmede, etkili bir liderlik sergilenmesinde ve bunun gibi mizahın pek çok olumlu etkisi yapılan araştırmalar tarafından ortaya çıkarılmıştır.

Stres

17. yüzyılda "bela, musibet, felaket, elem, keder, dert" gibi olumsuz anlamlarda kullanılan stres kavramı, daha sonra 18. ve 19. yüzyıllarda ise değişikliğe uğrayıp "güç, bask1, zor” gibi nesnelere, bireylere, uzuvlara ve psikolojik yapıya yönelik kullanılmaya başlanmıştır (Güçlü, 2001). Stresin modern çağda görünmeyen bir hastalık olduğu söylense de tarih öncesi dönemlerden bile günümüze dek var olduğu bilinmektedir (Rojas and Kleiner, 2000, s. 103). Asırlar boyunca değişsen 
koşullarla birlikte, insanın stres yaşamasına neden olan etkenler de değişmiştir. Tarih öncesi dönemlerde yabani hayvanlar, bulaşıcı hastalıklar ve savaşlarla ilişkili olarak ortaya çıkan stres kavramı günümüzde ekonomik, teknolojik ve sosyal olaylarla ilgili kendini göstermekte ve bu alanlardaki hızlı değişimlere paralel olarak devam etmektedir (Yılmaz ve Ekici, 2003). Yıldırım'a (1991) göre stres, organizmayı etkisi altına alan bir duruma karşı organizmanın fiziksel ve psikolojik sınırlarının zorlanması veya tehdit unsuru olarak algılanmasıyla ortaya çıkan tepkidir. Ertekin (1993, s. 5), stresin psikolojik temelli bir kavram olmasına rağmen bir müddet sonra bu olgunun fiziksel sonuçlarının da görülebileceğini ifade etmektedir. Lazarus ve Folkman (1984) stresi, bireyin kişilik özelliklerini de kapsayan birey ile çevre arasındaki ilişki ve çevresel faktörlerin birey üzerindeki etkisi olarak tanımlamıştır. Magnuson'a (1990) göre ise stres, bireyin gerçekte yaşadığı dünyası ile beklentileri arasındaki farklı1ıklara karşı sergilediği tepkidir.

Gibson, Iwancevich, Donelly ve Konopaske'nin (2012) kavramsallaştırdığı ve günümüzde en yaygın kullanılan tanım olarak stres; "bireysel farklılıklar ve psikolojik süreçler yoluyla gösterilen uyumsal bir davranım olup kişi üzerinde aşırı, psikolojik veya fiziksel baskı yapan herhangi bir dış veya iç hareket, durum ya da olayın organizmaya yansiyan sonucudur". Cüceloğlu'na (1994, s. 321) göre ise stres, "bireyin fiziksel ve sosyal çevresindeki uyumsuz koşullar nedeniyle, bedensel ve psikolojik sınırlarının ötesinde harcadığı gayrettir”. Stresin kaynağı farklı olsa da biyolojik olarak tepkisi hep aynıdır (Yates, 1986, s.29). Araştırmalar stresin öğrenmeyi ve insan belleğini etkilediğini göstermektedir. Shors (2006), stres ve ömür boyu öğrenmeyi konu alan çalışmasında, stresli durumlara maruz kalındığında korku ve göz kırpma gibi tepkilerin klasik koşullanma yoluyla öğrenilmesine neden olduğu sonucuna ulaşmıştır. Stresle karşılanan durumlarda, öğrenilenlerin bellekte depolanması ve geri çağrılmasının zorlaştığı belirtilmektedir. Stresi konu alan araştırmalar, stresin ruhsal sağlık ile güçlü bir bağlantısının olduğu vurgulamaktadır (Çevik ve Şentürk, 2008).

Stres; "gerilim, baskı, kaygı, tutarsızlık, sıkıntıya girme ve engellenme" gibi sözcüklerle de özdeşleşmektedir (Kaya ve Keskin, 2008). Başka bir tanıma göre, bireyin kendisinden kaynaklanan veya çevresindekilerle etkileşimi sonucunda ortaya çıkan, makul seviyede olduğunda gelişime katkısı olan; ancak aşırı düzeyde olduğunda organizmanın tüm yaşamsal ve ruhsal kaynaklarını tüketen bir süreç olarak değerlendirilir (Goldberger ve Breznitz, 1982). Sosyal (2009), stresi açıklarken bu durumun sadece basit bir endişeden ibaret olmadığını, sanılanın aksine stresin sakınılması gereken, zararlı bir durum olduğunu ifade etmektedir ve strese karşı alınacak bir önlemin olmadığı düşüncesine karşı çıkarak stresin sadece yetişkinler üzerinde etkili oluğu ya da sadece iş hayatına yönelik bir sorun olduğu yönündeki görüşlere mesafeli bakmaktadır. Stres, birey ile çevrenin birbiriyle etkileşimi sonucunda oluşur. Stresli bir durumda tehlikenin varlı̆̆ından söz edilebilir ve bu tehlikenin boyutu önemsenmelidir. "Kısttlama, firsat ve istekler" ile ilgili olan stres, organizmayı bütünüyle etkiler ve genellikle kontrol edilebilir bir tepki değildir (Aydın, 2004, s. 52 54; Tutar, Yılmaz ve Erdönmez, 2006, s. 189). Stresle ilgili açıklamaların bir kısmı uyarıcının 
önemine odaklanmışken, diğer kısmı da içsel tepkimenin ya da bedensel, ruhsal ve davranışsal savunmanın önemini vurgulamaktadır. Birçok araştırmacı ise, uyaran ve tepki etkileşiminde bireysel farkl111kları, bireyin başa çıkma mekanizmalarını önemsemektedir (R. L. Atkinson, Atkinson, Smith ve Hilgard, 1987). Işıkhan'a (2004) göre, strese ve stresin neden olduğu sonuçlara odaklanmanın giderek artmasının nedeni stresle ilgili hastalıkların gün geçtikçe yaygınlaşmasıdır.

Hızla gelişen teknolojik değişimler, bireyin yaşamdan beklentileri ya da çevrenin bireylerden beklentileri, hayatın hızı, aşırı iş yükü, sorumluluklar, trafik, kötü yaşam koşulları ve bunun gibi birçok faktör günümüz dünyasında insanları stres altına almaktadır. Stres konusunda yapılan birçok çalışma stresin yalnızca olumsuz yönlerini ortaya çıkarmıştır. Oysaki belirli düzeydeki stresin bazı durumlara katkısının olabileceği düşünülmektedir. Stresin olumlu etkilerinin ortaya koyulduğu bir araştırmada bunun kaçınılmaz olduğunu; ancak bazı başa çıkma yöntemleriyle denetim altında tutulabileceğini ve stresin yönetileceğini ifade edilmiştir. Stresi tamamen ortadan kaldırmak mümkün değildir. Makul bir düzeydeki stres insan hayatına ayrı bir renk ve tat katar, duyarlılık, dikkat ve motivasyonu arttırır (Durna, 2006). Hannigan, Edwards ve Burnard (2004, s. 235), makul seviyede stresin motivasyonu sağlayabileceği gibi, ilgi ve dikkati arttırabileceğini de ifade etmişlerdir. Diğer taraftan aşırı düzeyde algılandığında dikkati toplayamama, motivasyon eksikliği, devamsızlık, moralin düşmesi, tükenmişlik veya diğer fiziksel rahatsızlıkların ortaya çıkabileceğini söylemişlerdir (DeFrank ve Ivancevich, 1998, s.61).

Stres Kuramları

Stres kuramlar1; “Canon'un savaş ya da kaç modeli, Selye'nin genel uyum sendromu ve etkileşimsel kuram (bilişsel kuram)" olmak üzere üç grupta değerlendirilmektedir.

\section{Canon'un savaş/kaç modeli (fight or flight response)}

Walter Canon'a göre stres, organizmanın içsel dengesinin dışarıdan gelen uyarıcılarla bozulması durumunda ortaya çıkar. Canon bu süreci homeostatis ve "savaş-kaç tepkisi" kavramlarıyla açıklar. Canon, savaş-kaç tepkisinin bir yandan organizmanın tehditlere karşı aniden tepki vermesini olası bulduğu için uyumlu olduğunu, diğer yandan da stresin duygusal ve fiziksel işlevlerini bozan etkileri ve daha sonra ortaya çıkabilecek sağlık sorunlarını düşünerek zararlı olabileceğini savunmuştur (Taylor, 2003). Savaş ya da kaç tepkisi, insan ve hayvanlarda görülen, organizmanın tehlikeli bir durumda kaçmak ya da savaşmak için gerekli olan enerjiyi hızlı bir şekilde üretmesini sağlayan biyokimyasal bir reaksiyondur. Herhangi bir zamanda bireyin yüz yüze geldiği bir durum karşısında stres aniden kendini gösterir. Strese karşı sergilenen tutum, düşünce ve beklentiler kişinin stresi değerlendirme biçimini belirler. Stres karşısında verilen tepki "savaş ya da kaç” şeklinde olur. Bu tepkinin sonucunda karşılaşılan durum ise stresin sonuçlarını oluşturur (Rowshan, 2003, s. 21). 


\section{Genel uyum sendromu (general adaptation syndrome)}

Stresi ilk araştıran Hans Selye, insan vücudunun strese karşı verdiği üç aşamalı tepkiyi "Genel Uyum Sendromu” (General Adaptation Syndrome) olarak açıklamıştır. Buna göre; organizmanın stresli durumlara tepkisi üç aşamada gerçekleşir; "alarm tepkisi, direnme tepkisi ve tükenme.” (Z. Baltaş ve Baltaş, 1998, s. 26; Balcı, 2000, s. 21-23). Alarm tepkisi, organizmanın dış uyarıcıyı stres olarak algıladığı durumdur. Direnç tepkisi ise, stres yaratan koşullara karşı uyuma elverişli bir durum olarak tanımlanabilir. Bu dönemde vücut direnci normalin üzerindedir ve direnç devam ettiği sürece bedenin savunması zayıflar. Sonunda fiziksel tükenme dönemi başlar ve bu durum ölümle sonuçlanabilir. Bu aşama da tükenme aşaması olarak tanımlanmaktadır (Z. Baltaş ve Baltaş, 1998). Stresörler bedenin farklı alanlarını etkilediği için Selye savunma tepkisine 'genel' adını vermiştir. Uyum gösterme, stresle mücadele etme ya da strese karşı uyum göstermesi için düzenlenen savunma mekanizmalarıdır.

\section{Etkileşimsel kuram (transactional model)}

Lazarus (1966), stresin kişi ile çevresi arasındaki bir etkileşimi kapsadığını ve stresin ortaya çıkmasının ancak kişinin stresli bir durumu stres verici olarak tanımlamasıyla mümkün olduğunu söylemiştir. Bireylerin algıladıkları stres yoğunluğu, onların olaylara yüklediği anlamlarla bağlantılıdır. Bu anlamlandırma süreci birincil ve ikincil değerlendirme süreçlerini de içermektedir. Birincil değerlendirme sürecinde kişi olaya verdiği önemi değerlendirir ve olayı tehdit edici, kayıplar verdiren veya zarar verici olarak algılayabilir. Örneğin, işini kaybeden biri durumu kendisi ve ailesi için ekonomik açıdan güçlük yaratacağını düşünürse, bu durum potansiyel bir stres kaynağı olarak tanımlanabilir. Fakat aynı kişinin, işsiz kalmayı yeni bir iş imkanının doğması olarak algılamasıyla birlikte potansiyel stres kaynağı ortadan kalkar (Lazarus, 1966). Baltaş ve Baltaş’a (2008) göre, eğer organizma durumu tehdit olarak algılarsa, aynı anda ikincil değerlendirme süreci başlamış demektir. $\mathrm{Bu}$ aşamada, organizmanın stres verici durumla başa çıkma mekanizmalarının baş etme gücünü zihinsel olarak değerlendirmesidir yani bir bakıma "zihinsel muhasebe" sürecidir.

\section{Stresin Belirtileri}

Modern insanın günlük yaşantısının bir kısmını oluşturan stresin pek çok belirtisi bulunmaktadır. Stresin; gerginlik, sürekli kaygı duyma, aşırı alkol ve sigara tüketimi, uykusuzluk, işbirliği yapamama, yetersizlik hissi, duygusal dengesizlik, hazım sorunları ve yüksek tansiyon gibi kendine özgü belirtileri vardır (Davis, 1984, s.439'dan akt. Pehlivan, 1995, s. 45). Stresin belirtileri, fizyolojik, psikolojik, zihinsel ve sosyal olmak üzere dört şekilde gruplandırılabilir (Braham, 1998, s. 52-54).

\section{Stresin Sonuçları}

Stresin bedensel ve ruhsal sağlık üzerinde ortaya çıkardığı olumsuz sonuçlara ek olarak, örgütsel sağlık üzerinde de olumsuz sonuçlar yarattığını söylemek mümkündür. Bu durum stresin 
neden olduğu sorunları bireysel ve örgütsel açıdan incelemeyi gerektirir. Schermerhorn, Hunt ve Osborn'un(1988) stres kaynakları ve potansiyel sonuçları Şekil 1'de verilmiştir:

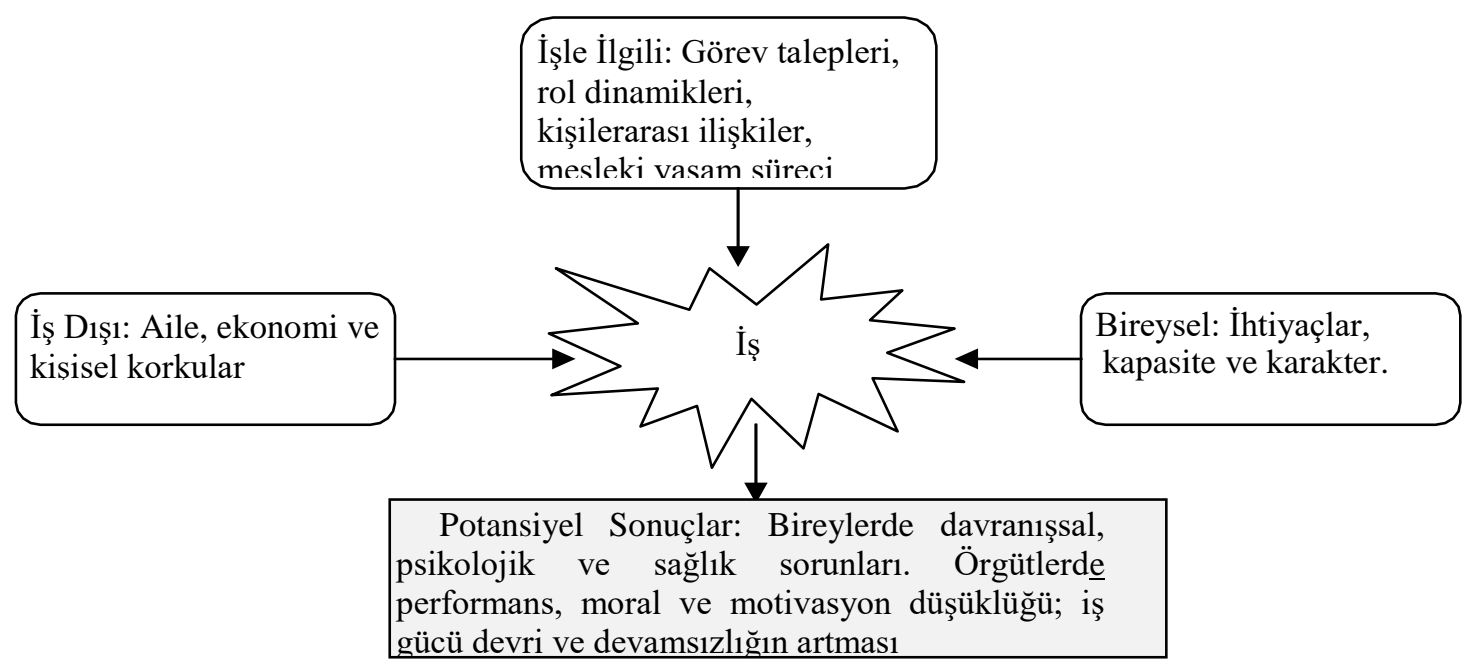

Şekil 1. Stres kaynakları ve potansiyel sonuçları

Kaynak: Schermerhorn, J.R., Hunt, J.G., \& Osborn, R.N. (1988). Managing Organizational Behavior. (3rd Edition). New York: John Wiley \& Sons.

\section{Öğretmenlik Mesleği ve Stres}

Teknoloji, iletişim ve bilgi alanlarındaki gelişmelerin, beklentilerin ve gittikçe zorlaşan yaşam koşullarının sonucunda ortaya çıkan stres, günümüz dünyasındaki tüm bireyleri etkilemektedir. Her örgütte yapılan işe, işin yapılış şekline, çevresel koşullara, çalışanların eğitim düzeylerine ve geçmiş yaşam tecrübelerine, gruplaşmalara, iklime ve diğer bazı değişkenlere göre stres kaynakları geliştirilir (Öztürk, 1995). Çalışma koşulları ve bu koşullardan kaynaklanan stres de işgörenin performansını, yaşamdan ve işinden aldığı doyumu doğrudan etkilemektedir. Çeşitli meslekler üzerinde yapılan bir araştırmada, infaz memurluğu, polislik, öğretmenlik, akademisyenlik, ambulans şoförlüğü, askerlik, maden işçiliği, gazetecilik, aktörlük, doktorluk, diş hekimliği ve itfaiyecilik gibi mesleklerin yüksek düzeyde stresli meslek grupları olduğu belirtilmektedir (Hargreaves, 1999, s.35). Z. Baltaş ve Baltaş'a (2008) göre, çalışma saatleri göz önünde bulundurulduğunda, birey vaktinin büyük çoğunluğunu iş ortamında harcamakta ve burada yaşanan her gelişme bireyin günlük hayatına yansımaktadır. Kişinin sahip olduğu meslek, onun toplum içerisindeki yerini, hayattan aldığı doyumu ve ailesine sunduğu imkanları belirlemektedir. Öğretmenlerde stresin ortaya çıkışı, kişilik özelliklerinden veya örgütün kendi özelliklerinden kaynaklı olarak her çalışanda faklı şekilde ortaya çıkabilir. Değişen çevre koşulları, malzemesi insan olan ve aşırı stresli meslek gruplarından biri olarak tanımlanan öğretmenleri büyük ölçüde etkisi altına almaktadır. Alanyazında, kişilerarası iletişimin yoğun olduğu mesleklerin bireylerde daha yüksek strese neden olduğu ve bu nedenle de öğretmenlik mesleğinin yüksek stresli olduğu belirtilmektedir. Sandıkçı’ya (2010) göre, öğretmenler işlerini yaparken, öğrenciler, veliler, diğer personeller, yöneticiler ve çevresiyle çok yönlü ve yoğun bir şekilde ilişki içindedir. Bu ilişkiler 
çatışma, birbirini eleştirme, baskı kurma ve yetersizlik gibi sorunları oluşturabilir. Disiplini sağlamada yaşanan sorunlar, kalabalık sınıflar ve fiziki şartlardaki yetersizlik öğretmen stresini arttırmaktadır. Öğretmen stresi, öğretmenin işini yaparken öfke, gerilim, depresyon gibi olumsuz durumları yaşaması olarak tanımlanabilir (Kyriacou, 2001). Ayrıca, öğretmenlerin yaşadıkları ekonomik zorluklar ve kaygılar, ödül sistemindeki aksaklıklar, bilgi akışındaki yetersizlikler ve yöneticilerin kullandıkları liderlik tarzları öğretmenlerin stresle karşı karşıya gelmesine neden olmaktadır (Öztürk, 1995). Öğretmenlerde stres, öfke, kaygı, hayal kırıklığı ve depresyon gibi olumsuz duyguların oluşmasına neden olabilir. Kalabalık sınıflar ve diğer çalışanlarla yaşanan sıkıntılar öğretmenlerin strese maruz kalmalarına zemin hazırlar. Bu anlamda, öğretmenlerin yaşadıkları stres, fizyolojik ve psikolojik etkenlerden kaynaklanabilir (Dick ve Wagner, 2001).

Doğan'a (2008) göre, öğrencilerdeki öğrenmeye karşı isteksizlik, disiplinsizlik, zaman baskısı ve aşırı iş yükü, değişikliklere uyum sağlama, öz saygı, toplumsal statü, idareci ve yöneticilerin beklentilerini karşılama, meslektaşlarla uğraşma, rol çatışması ve rol belirsizlikleri, olumsuz çalışma şartları gibi pek çok ana stres faktörü öğretmenleri olumsuz yönde etkilemektedir. Yang, Ge, Chi ve Wang (2009), genel nüfus ortalamasına bakıldığında öğretmenlerin sağlılı olma oranlarının daha düşük olduğunu ve kadın öğretmenlerin erkeklere göre stresi daha yüksek düzeyde algıladıkları sonucunu ortaya koyarken, aşırı iş yükü, derse hazırlık süreci, yöneticilerin verdiği diğer sorumluluklar, öğrenci ve velilerle yaşanan iletişim sorunları da öğretmenlerde strese neden olan faktörler olarak sıralanmaktadır. Litt ve Turk (1985), öğretmenlikte yaşanan stresin en büyük kaynağ1 ve öğretmenlerin işten ayrılmalarının nedenini okul müdürüyle yaşanan sorunlar olarak göstermiştir. Blase (1984), öğretmenlerin müdürleri genellikle strese ya da strese zemin oluşturan durumlara sebep olan kişiler olarak düşündüklerini iler sürmektedir. Stresin hem öğretmenin hem de öğrencinin performansını etkilediği vurgulanmıştır. Çalışanlarıyla mizahı paylaşmayan yöneticiler stres kaynağı olabilir. Özellikle de okul yöneticileri öğretmenlerin stres kaynağı olarak görülmektedir (Blase, Dedrick ve Strathe, 1986). Aydın (2008), öğretmenlikte stres kaynaklarının sebeplerini, ilgili bakanlığın öğretmenlere sahip çıkmaması, eğitim sistemi kalitesindeki düşüş, eğitime siyasetin karıştırılması, nitelikli öğretmenlerin yetiştirilememesi, öğretim programları içeriğinin gereksiz ayrıntılarla doldurulması ve eğitime gereken önemin gösterilmemesi olarak sıralamıştır. Chapman ve Foot' a (1996, s. 193) göre, “gülmenin ve mizahın gerilimi azalttığı” bir gerçektir. Yöneticiler çalışma alanlarında mizah yeteneklerini paylaşmazlarsa stresin doğrudan bir kaynağı olarak düşünülebilir. Liderler, özellikle okul yöneticileri öğretmenlerin stres yaşama nedeni olarak görülmektedir (Blase vd., 1986).

Bu araştırmada, ilkokul yöneticilerinin bir kişilik özelliği olarak mizahı kullanma tarzları ile öğretmenlerin stres yaşama düzeyleri arasındaki ilişki bazı değişkenlere göre incelenmiştir. Bu ilişkiyi saptamaya yönelik kavramsal altyapı kurularak, kavramların birbirleriyle etkileşimi kuramsal bazda ele alınıp tartışılmıştır. Yöneticilerin mizah kullanma tarzlarının öğretmenlerin stres yaşama 
düzeyini yordamasının yapıldığı sınırlı sayıda çalışma yapıldığı tespit edilmiştir. Bu çalışmada, ilkokul yöneticilerinin mizah tarzları belirlenerek, kullandıkları mizah tarzlarının öğretmenleri ne düzeyde ve nasıl etkilediğini ortaya koyacak ve bu etkileşimde öğretmenlerin stres yaşama düzeyi ortaya çıkarılarak alana katkı sağlanması beklenmektedir.

$\mathrm{Bu}$ araştırmanın amacı, ilkokul yöneticilerinin mizah kullanma tarzları ile öğretmenlerin stres yaşama düzeyleri arasındaki ilişkiyi saptamak ve bazı demografik değişkenlere göre incelemektir. Bu amaca ulaşabilmek için şu sorulara cevap aranmıştır:

1.Öğretmenlerin algılarına göre, ilkokul yöneticilerinin mizah kullanma tarzları ve öğretmenlerin stres yaşama düzeyleri nedir?

2. Öğretmenlerin algılarına göre, okul yöneticilerinin mizah kullanma tarzları ile öğretmenlerin stres yaşama düzeyleri arasında anlamlı bir ilişki var mıdır?

3. İlkokul yöneticilerinin mizah kullanma tarzları öğretmenlerin stres yaşama düzeylerinin anlamlı bir yordayıcısı midır?

4. İlkokul yöneticilerinin mizah kullanma tarzları öğretmenlerin stres yaşama düzeylerinde; cinsiyet, yaş, kıdem, branş, medeni durum, mesleği sevme, sosyo-ekonomik ve mesleği bırakma durumlarına göre anlamlı bir farklılık göstermekte midir?

Araştırmanın bulguları, eğitim ve öğretim ortamında önemli rolleri olan okul yöneticileri, eğitim uzmanları, eğitim yöneticileri, öğretmenler ve bu konuda çalışma yapan araştırmacılara önemli bazı veriler sunacağı düşünülmektedir. Öncelikle okul yöneticilerinin mizahi tarzlarının belirlenmesi ile kullandıkları mizah tarzlarının okullarındaki öğretmenleri, öğrencileri ve tüm okul çalışanlarını etkileyen sorunları çözmesine yardımcı olacağı düşünülmektedir. Araştırma bulgularının, okul yöneticilerinin; okulun gelişmesine, sağlıklı bir örgüt iklimi ve kültürünün oluşmasına yardımcı olan etmenleri görüp problemlere yol açan durumları çözmede, etkili ve doğru liderlik uygulanmasında önemli katkılarının olacağı öngörülmektedir. Araştırmada genel olarak, hangi mizah tarzının strese neden olduğunu, hangi mizah tarzının stres oluşumunu etkilediğini, sonuç olarak mizah kullanma tarzlarının ve strese neden olan unsurların belirlenmesinde rol oynayan değişkenlerin tanımlanmasına ve anlaşılmasına olanak sağlayacağı beklenmektedir.

\section{YÖNTEM}

\section{Araştırmanın Modeli}

Araştırmanın deseni ilişkisel tarama modeli olarak belirlenmiştir. "İlişkisel araştırma, değişkenler arası ilişkileri belirlemek için yapılabilir” (Büyüköztürk, Çakmak, Akgün, Karadeniz ve Demirel, 2008, s. 221). Karasar'a (2008, s.81) göre, ilişkisel tarama modelleri, "iki veya daha fazla değişken arasındaki birlikte değişim varlığını ve derecesini belirlemeyi amaçlayan araştırma modelleridir”. Bu araştırmanın modelinde, okul yöneticilerinin mizah kullanma tarzları bağımsız 
değişken, öğretmenlerin stres yaşama düzeyi bağımlı değişken olarak ele alınmaktadır. Ayrıca, diğer bağımsız değişkenler, öğretmenlerin cinsiyetleri, yaşları, branşları, kıdemleri, medeni durumları, öğretmenlik mesleğini sevme, mesleği bırakma durumları ve sosyo-ekonomik düzeylerinden oluşmaktadır.

\section{Evren ve Örneklem}

Araştırmanın evrenini Ankara ili Çankaya ilçesindeki farklı sosyo-ekonomik seviyelerde (düşük, orta, yüksek) bulunan 75 resmi ilkokulda görev yapan 1636 öğretmen oluşturmaktadır. Örneklem için belirlenen ilçede bulunan 30 okuldan 311 öğretmene ulaşılmış; ancak 11 anket analiz öncesi çıkartılmıştır. Araştırmada, veri toplama aracı olarak, Mizah Davranışları Ölçeği (MDÖ) ve Algılanan Stres Ölçeği (ASÖ) kullanılmıştır. Verilerin analizinde parametrik testler; n, aritmetik ortalama, pearson momentler çarpımı korelasyon katsayısı, regresyon analizi, independent sample ttesti ve tek yönlü varyans analizi kullanılmıştır.

Veri Toplama Araçları

Araştırmada, Algılanan Stres Ölçeği (ASÖ) ve Mizah Davranışları Ölçeği (MDÖ) kullanılmıştır. ASÖ ilk olarak Cohen, Kamarck ve Mermelstein (1983) tarafından geliştirilmiş, Cronbach Alpha değeri 0.86 bulunmuştur. ASÖ, yaşanan stresin düzeyini, katılımcının yaşamını ne derece yordanamaz ve kontrol edilemez değerlendirdiğine bağlı olarak ölçmek üzere geliştirilmiş bir kendini değerlendirme ölçeğidir. Yerlikaya (2003) tarafından Türkçeye uyarlanan ASÖ, toplam 14 maddeden oluşan, kişinin hayatındaki bazı durumlarda son bir ay içinde stresi ne derece algılandığını ölçme amaciyla geliştirilmiştir. Pozitif anlamlar içeren 7 madde 4,5,6,7,9,10,13 tersten puanlanmaktadır. MDÖ ise, Cemaloğlu ve diğerleri (2012) tarafından geliştirilen 30 maddelik bir ölçektir. Ölçekte olumlu ve olumsuz sorular karışık bir sırayla verilmiştir. Ölçeğin güvenirliğini tespit etmek amacıyla Cronbach Alpha uygulanmış ve güvenirlik katsayı değeri 0.91 bulunmuştur. "Alaycı mizah, üretici-sosyal mizah, onaylayıc mizah, reddedici mizah ve mizahi olmayan tarz" olmak üzere beş boyutta ele alınmıştır. Her iki envanterde likert tipi ölçekler kullanılmıştır. Likert tipi ölçekler, ölçülmek istenen durumun farklı boyutlarını ortaya koymak için kullanılır. Likert ölçekleri tutum ölçümlerinde sıklıkla kullanılan bir ölçek türüdür ve önceden oluşturulan faktörlere, bu faktörlerin içerdiği maddelere kişilerin ne oranda katıldıklarını ortaya koymak için kullanılır. Katılımcılar her maddeyi "Hiç katılmıyorum (1), Az Katılıyorum (2), Orta Düzeyde Katılıyorum (3), Çok Katılıyorum (4) ile Tamamen katılıyorum (5)" arasında değişen 5'li Likert tipi ölçek üzerinde değerlendirmektedir.

Bu çalışmada, MDÖ ve ASÖ’ nün Cronbach Alpha değeri 0.82 bulunmuştur. Araştırmaya ilişkin istatistikler için SPSS 24 programı kullanılmıştır. Verilerin parametrik ya da nonparametrik olduğunu anlamak için ve 50' den fazla veri olduğu için Kolmogorov-Smirnov testi yapılmış, test sonucuna göre anlamlı bir farklılığın olmadığı ve dağılımın parametrik özellikler taşıdığı anlaşılmıştır. Verilerin normallik dağılımı Tablo 1' de verilmiştir. 
Tablo 1

Normallik Dağılımı

\begin{tabular}{lcccccc}
\hline & \multicolumn{3}{c}{ Kolmogorov-Smirnov } & \multicolumn{3}{c}{ Shapiro-Wilk } \\
\cline { 2 - 7 } & İstatistik & sd & P $>.05$ & İstatistik & sd & $\mathrm{P}<.05$ \\
\hline Veriler & .05 & 240 & .07 & .97 & 240 & .00 \\
\hline
\end{tabular}

Normalliğe ilişkin histogram Şekil 2' de verilmiştir:

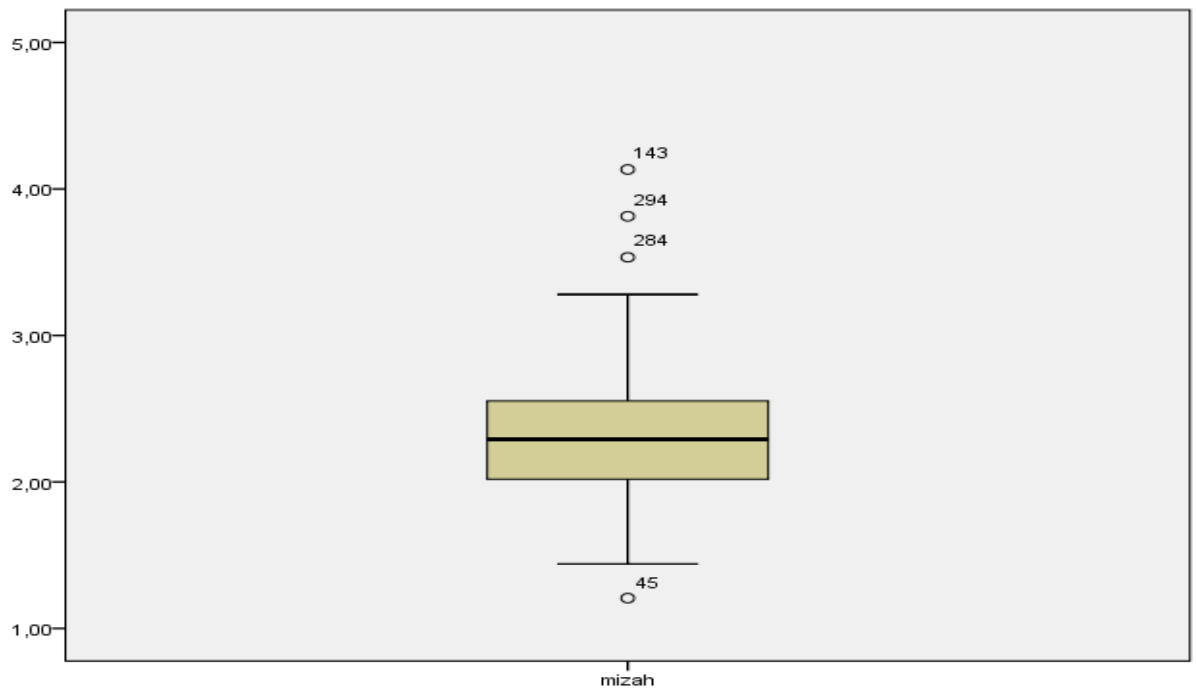

Şekil 2. Normalliğe ilişkin histogram

\section{Verilerin Analizi}

Verilerin analizi iki aşamada yapılmıştır. Birinci aşamada, bilgisayar ortamına aktarılan veriler eksik veya hatalı değerler incelenmiş; ikinci aşamada ise araştırmanın alt problemleri çözümlenmiştir. Araştırmanın analizinde parametrik testler; n, aritmetik ortalama, pearson momentler çarpımı korelasyon katsayısı, regresyon analizi, independent sample t-testi ve tek yönlü varyans analizi kullanılmıştır. Anlamlılık düzeyi $\mathrm{p}<.05$ düzeyinde test edilmiştir.

\section{BULGULAR}

Araştırmanın bu bölümünde tanımlayıcı istatistikler, değişkenler arası korelasyonlara ve regresyon analizi sonucunda elde edilen bulgulara yer verilmiştir. Öğretmen algılarına göre okul yöneticilerinin mizah kullanma düzeylerine ilişkin dağılım Tablo 2'de verilmiştir: 
Tablo 2

Öğretmenlerin Okul Yöneticilerinin Mizah Kullanma Düzeylerine İlişkin Tanımlayıcı İstatistikler

\begin{tabular}{lccccc}
\hline Boyutlar & $n$ & Minimum & Maksimum & $\bar{X}$ & $S$ \\
\hline Alayc1 & 282 & 1.00 & 5.00 & 1.54 & .91 \\
Üretici sosyal & 271 & 1.00 & 5.00 & 2.40 & .86 \\
Onaylayic1 & 283 & 1.00 & 5.00 & 3.27 & 1.02 \\
Reddedici & 282 & 1.00 & 5.00 & 2.00 & .71 \\
Mizahi Olmayan & 300 & 1.00 & 5.00 & 2.33 & .08 \\
\hline Stres & 257 & 1.36 & 4.50 & 2.77 & .53 \\
\hline
\end{tabular}

Tablo 2' de verilen öğretmenlerin okul yöneticilerinin mizah kullanma düzeylerine ilişkin tanımlayıcı istatistikler incelendiğinde; okul yöneticilerinin en fazla orta düzeyinde ( $\bar{x}=3.27)$ onaylayıcı mizahı kullandıkları, en az hiç düzeyinde $(\overline{\mathrm{X}}=1.54)$ alaycı mizahı kullandıkları görülmektedir. Diğer mizah türleri ise sırasıyla; üretici-sosyal $(\overline{\mathrm{X}}=2.40)$, mizahi olmayan tarz $(\bar{X}=2.33)$ ve reddedici mizah $(\bar{X}=2.00)$ olduğu görülmektedir. Öğretmenlerin strese ilişkin algıları incelendiğinde, stresin orta düzeyinde $(\overline{\mathrm{X}}=2.77)$ olduğu görülmektedir. Standart sapma değerleri incelendiğinde, en homojen değerlendirmenin $S=.53$ ile strese, en heterojen değerlendirmenin ise $\mathrm{S}=1.08$ düzeyinde mizahi olmayan tarza ait olduğu ortaya konulmuştur. Başka bir anlatımla, okul yöneticileri en fazla onaylayıcı, en az alaycı mizah tarzını kullanmakta ve öğretmenler orta düzeyde stres yaşamaktadır. Öğretmen algılarına göre okul yöneticilerinin kullandıkları mizah tarzları ve öğretmenlerin stres yaşamaların ilişkin dağılımı Tablo 3' te verilmiştir:

Tablo 3

Öğretmen Görüşlerine Göre Okul Yöneticilerinin Kullandıkları Mizah Tarzları ve Öğretmenlerin Stres Yaşama Düzeylerine İlişkin Pearson Momentler Çarpımı Korelasyon Katsayısı Dağılımı

\begin{tabular}{|c|c|c|c|c|c|c|c|}
\hline Değişkenler & 1. & 2. & 3. & 4. & 5. & 6. & 7. \\
\hline 1. Alaycı & - & .41 & -.28 & $.58 * *$ & $.30 * *$ & $.66 * *$ & $.20 * *$ \\
\hline 2. Üretici sosyal & & - & $.73 * *$ & -.11 & $-.47 * *$ & $.46^{* *}$ & .11 \\
\hline 3. Onaylayıcı & & & - & $-.25 * *$ & $-.53 * *$ & $.26 * *$ & -.00 \\
\hline 4. Reddedici & & & & - & $.48 * *$ & $.46 * *$ & $.19 * *$ \\
\hline 5. Mizahi Olmayan & & & & & - & $.33 * *$ & .11 \\
\hline 6. Stres & & & & & & & - \\
\hline
\end{tabular}

Tablo 3' te verilen öğretmen görüşlerine okul yöneticilerinin kullandıkları mizah tarzları ve öğretmenlerin stres yaşama düzeylerine ilişkin dağ 11 lı incelendiğinde; okul yöneticilerinin kullandıkları alaycı mizah tarzları ile öğretmenlerin stres yaşama düzeyleri arasında düşük ve pozitif yönde $(\mathrm{r}=.20 \mathrm{p}<.05)$ anlamlı bir ilişkinin olduğu, reddedici mizah tarzı ile stres arasında düşük ve pozitif yönde $(r=.19 \mathrm{p}<.05)$ anlamlı bir ilişkinin olduğu, onaylayıcı mizah tarzı ile stres arasında negatif yönlü düşük (r=-.00 p>.05) ve anlamsız bir ilişkinin olduğu ortaya konumuştur. Üreticisosyal ve mizahi olmayan tarz ile stres arasinda $(r=.11 \mathrm{p}>.05)$ ve $(r=.11 \mathrm{p}>05)$ anlamlı bir farkl11ık bulunamamıştır. Determinasyon katsayıları incelendiğinde; alaycı mizah ile stresin $r^{2}=.20 \%$ 'ünü açıkladığı, reddedici mizah ile stresin $\mathrm{r}^{2}=.19 \%$ 3'ünü açıkladığı sonucuna ulaşılmıştır. Başka bir 
anlatımla, okul yöneticileri alaycı ve reddedici mizah tarzını kullandıklarında öğretmenlerin stres düzeyleri artarken, üretici-sosyal ve mizahi olmayan tarzı kullandıklarında öğretmenlerin stres yaşamalarında etkili olmamakta, onaylayıcı mizahı kullandıklarında ise öğretmen stresi azalmaktadır. Okul yöneticilerinin kullandıkları mizahın öğretmenlerin stres yaşamasına ilişkin regresyon analizi sonuçları Tablo 4' te verilmiştir.

Tablo 4

Okul Yöneticilerinin Kullandıkları Mizah ile Öğretmenlerin Stres Yaşamasına İlişkin Regresyon Analizi

\begin{tabular}{lccccccc}
\hline Değişkenler & \multicolumn{3}{c}{ Standart Hata } & $\beta$ & $t$ & $p$ & \multicolumn{2}{c}{ Ikili } & \multicolumn{2}{c}{ Klsmi } \\
\hline Sabit & 2.17 & .22 & - & 9.57 & .00 & - & - \\
Alayc1 & .06 & .05 & .09 & 1.13 & .26 & .07 & .07 \\
Üretici-sosyal & .14 & .07 & .22 & 2.04 & .04 & .14 & .13 \\
Onaylayıc1 & -.03 & .05 & -.07 & -.63 & .52 & -.04 & -.04 \\
Reddedici & .12 & .06 & .16 & 1.83 & .06 & .12 & .12 \\
Mizahi Olmayan & .02 & .04 & .05 & .59 & .55 & .04 & .03 \\
\hline
\end{tabular}

$\mathrm{R}=.30, \mathrm{R}^{2}=.09, \quad \mathrm{~F}_{(5,208)}=4.29, \quad p=0.001 *$

Tablo 20'de verilen okul yöneticilerinin kullandıkları mizah tarzları ile öğretmenlerin yaşadıkları strese ilişkin regresyon analizi sonuçları incelendiğinde; düşük düzeyde $\mathrm{R}=.30 \mathrm{R}^{2}=.09$ $\mathrm{p}<.01$ anlamlı bir ilişki olduğu görülmektedir. Okul yöneticilerinin kullandıkları üretici-sosyal, onaylayıc1, reddedici, mizahi olmayan tarz ile birlikte stresin toplam varyansının yaklaşı \% \%'unu açıklamaktadır. Standardize edilmiş regresyon katsayısına $(\beta)$ göre, yordayıcı değişkenlerin göreli önem sırası; onaylayıcı, üretici-sosyal, alaycı, reddedici ve mizahi olmayan tarzdır. Regresyon katsayılarına ilişkin t-testi sonuçları incelendiğinde ise, sadece üretici-sosyal mizahın stres üzerinde anlamlı bir yordayıcı olduğu görülmektedir. Diğer değişkenler, alaycı, onaylayıcı, reddedici ve mizahi olmayan tarz anlamlı bir yordayıcı değildir. Bu analiz sonucuna göre stresin yordanmasına ilişkin regresyon eşitliği;

STRES $=2.17+.06 A L A Y C I+.14 \ddot{U} R E T I C \dot{I}+.12 R E D D E D \dot{I} \dot{I}+.02 M I Z A H I O L M A Y A N+.03 O N A$ YLAYICI 
Öğretmenlerin cinsiyetleri ile okul yöneticilerinin mizah kullanma tarzları ve strese ilişkin dağılım Tablo 5'te verilmiştir.

Tablo 5

Okul Yöneticilerinin Mizah Kullanma Tarzları ve Strese İlişkin Öğretmenlerin Cinsiyetlerine Göre t-Testi

\begin{tabular}{|c|c|c|c|c|c|c|c|}
\hline Mizah Boyutları & Cinsiyet & $n$ & $\bar{x}$ & $S$ & $s d$ & $T$ & $P<.05$ \\
\hline \multirow[t]{2}{*}{ Alaycı } & Kadın & 223 & 1.57 & .96 & 279 & 2.07 & $.04 *$ \\
\hline & Erkek & 58 & 1.36 & .60 & & & \\
\hline \multirow[t]{2}{*}{ Üretici sosyal } & Kadın & 217 & 2.33 & .85 & 268 & 2.39 & $.01 *$ \\
\hline & Erkek & 53 & 2.64 & .83 & & & \\
\hline \multirow[t]{2}{*}{ Onaylayıcı } & Kadın & 228 & 3.23 & 1.02 & 280 & 1.28 & .19 \\
\hline & Erkek & 54 & 3.42 & .98 & & & \\
\hline \multirow[t]{2}{*}{ Reddedici } & Kadın & 227 & 2.01 & .72 & 279 & 1.26 & .21 \\
\hline & Erkek & 54 & 1.89 & .61 & & & \\
\hline \multirow[t]{2}{*}{ Mizahi Olmayan } & Kadın & 240 & 2.36 & 1.08 & 297 & 1.36 & .17 \\
\hline & Erkek & 59 & 2.15 & 1.06 & & & \\
\hline \multirow[t]{2}{*}{ Stres } & Kadın & 206 & 2.79 & .54 & 255 & 1.19 & .23 \\
\hline & Erkek & 51 & 2.69 & .49 & & & \\
\hline
\end{tabular}

Tablo 5' te verilen öğretmenlerin cinsiyetlerine göre, okul yöneticilerinin kullandıkları mizah tarzları arasındaki fark için hesaplanan t-testi dağılımları incelendiğinde; kadın ve erkek öğretmenler, okul yöneticilerinin en fazla $(\overline{\mathrm{X}}=3.23$ ve $\overline{\mathrm{X}}=3.42)$ orta düzeyinde onaylayıcı mizahı kullandıklarını ileri sürerken, en az ( $\overline{\mathrm{X}}=1.57$ ve $\mathrm{X}=1.36)$ hiç düzeyinde alaycı mizahı kullandıklarını ileri sürmektedirler. Standart sapma değerleri incelendiğinde, en homojen değerlendirmeyi streste $\mathrm{S}=.49$ erkeklerin, en heterojen değerlendirmeyi ise mizahi olmayan tarzda $\mathrm{S}=1.08$ kadın öğretmenlerin yaptıkları ortaya konmuştur. Öğretmenlerin cinsiyetleri ile okul yöneticilerinin kullandıkları mizah tarzları arasında alaycı $[t(279)=2.07, \mathrm{p}<.05]$ ve üretici-sosyal $[t(239)=2.39$, $\mathrm{p}<.05]$ alt boyutlarında anlamlı bir farklılık varken; onaylayıc1 $[t(280)=1.28 \mathrm{p}>.05]$, reddedici [ $\mathrm{t}$ $(279)=1,26 \mathrm{p}>.05]$, mizahi olmayan tarz $[t(297)=1.36 \mathrm{p}>.05]$ ve stres $[t(255)=1.19 \mathrm{p}>05]$ arasında anlamlı bir farklılık bulunamamıştır. Başka bir anlatımla, kadın öğretmenler okul yöneticilerinin daha fazla alaycı mizahı, erkek öğretmenler ise okul yöneticilerinin daha fazla üreticisosyal mizahı kullandıklarını ileri sürmüş, onaylayıcı, reddedici ve mizahi olmayan tarz da ise cinsiyete göre farklılık olmadığı saptanmıştır. Öğretmenlerin yaşları ile okul yöneticilerinin mizah tarzları ve strese ilişkin dağılım Tablo 6'da verilmiştir:

Tablo 6

Öğretmenlerin Yaşları ile Okul Yöneticilerinin Mizah Tarzları ve Strese İlişkin ANOVA

\begin{tabular}{llccccccc}
\hline Boyutlar & Yaş & $n$ & $\bar{X}$ & $S$ & $s d$ & $F$ & $p<.05$ & Scheffe \\
\hline \multirow{4}{*}{ Alayc1 } & $21-30$ & 28 & 1.27 & .49 & 3 & & & $31-40$ \\
& $31-40$ & 72 & 1.30 & .62 & 278 & 4.08 & $.00^{*}$ & $41-50$ \\
& $41-50$ & 129 & 1.71 & 1.03 & 281 & & & \\
Üretici sosyal & $51+$ & 53 & 1.58 & 1.03 & & & & \\
& $21-30$ & 28 & 2.42 & .78 & 3 & & & \\
& $31-40$ & 70 & 2.39 & .85 & 267 & 0.15 & .92 & \\
& $41-50$ & 124 & 2.42 & .88 & 270 & & & \\
& $51+$ & 49 & 2.33 & .85 & & & & \\
& $21-30$ & 27 & 3.55 & .89 & 3 & & & \\
\hline
\end{tabular}




\begin{tabular}{llccccccc}
\hline Onaylayic1 & $31-40$ & 70 & 3.33 & 1.02 & 279 & 1.07 & .36 & - \\
& $41-50$ & 136 & 3.21 & 1.07 & 282 & & & \\
& $51+$ & 50 & 3.17 & .91 & & & & \\
& $21-30$ & 28 & 1.92 & .50 & 3 & & & \\
Reddedici & $31-40$ & 73 & 1.92 & .65 & 278 & .67 & .57 & \\
& $41-50$ & 131 & 2.06 & .77 & 282 & & & \\
& $51+$ & 50 & 1.99 & .72 & & & & \\
Mizahi & $21-30$ & 28 & 2.14 & 1.04 & 3 & & & \\
Olmayan & $31-40$ & 75 & 2.21 & 1.10 & 296 & 1.02 & .38 & \\
& $41-50$ & 142 & 2.43 & 1.09 & 299 & & & \\
Stres & $51+$ & 55 & 2.32 & 1.05 & & & & \\
& $21-30$ & 26 & 2.84 & .34 & 3 & & & \\
& $31-40$ & 64 & 2.81 & .58 & 253 & .42 & & \\
& $41-50$ & 122 & 2.74 & .52 & 256 & & & \\
\hline
\end{tabular}

Tablo 6' da verilen öğretmenlerin yaşlarına ile okul yöneticilerinin mizah tarzları ve strese ilişkin varyans değerleri incelendiğinde; $41-50(\bar{X}=1.71)$ ve 51 ve üzeri $(\bar{X}=1.58)$ yaş grubunda olan öğretmenler hiç düzeyinde diğer yaş gruplarına göre okul yöneticilerinin daha fazla alaycı mizah tarzını kullandıklarını ileri sürmektedirler. Diğer yaş gruplarında olanlar ise, 41-50 ( $\bar{X}=2.42)$ yaş arasında olanlar yöneticilerin, üretici-sosyal mizahı, 21-30 $(\overline{\mathrm{X}}=3.55)$ yaş arasında olanlar onaylayıcı mizahı, 41-50 ( $\overline{\mathrm{X}}=2.06)$ yaş arasında olanlar reddedici mizahı, 41-50 ( $\mathrm{X}=2.43)$ yaş arasında olanlar mizahi olmayan tarzı kullandıklarını düşünmektedir. Stres yaşama düzeyleri incelendiğinde ise, 21$30(\overline{\mathrm{X}}=2.84)$ yaş grubunda olan öğretmenlerin orta düzeyinde stres yaşadıkları anlaşılmaktadır. Standart sapma değerleri incelendiğinde, en homojen değerlendirmeyi alaycı mizah tarzında $S=.49$ 21-30 yaş grubunda, üretici-sosyal mizah tarzında $\mathrm{S}=.78$ 21-30 yaş grubunda, onaylayıcı mizah tarzında $S=.89$ 21-30 yaş grubunda, reddedici mizah tarzında $S=.50$ 21-30 yaş grubunda, mizahi olmayan tarz da ise $S=1.04$ 21-30 yaş grubundakiler oluşturmaktadır. Öğretmenlerin yaşları ile okul yöneticilerinin mizah tarzlarındaki arasındaki varyans incelediğinde, alaycı mizahta yaşa göre anlamlı bir farklılık bulunmaktadır $[F(3-278)=4.08 \mathrm{p}<05]$. Farklılığın hangi gruplar arasında olduğunu saptamak amaciyla hesaplanan Scheffe testine göre, 31-40 ve 41-50 yaş grupları arasında olduğu saptanmıştır. 41-50 yaş grubundaki öğretmenler, 31-40 yaş gurubundakilere göre okul yöneticilerinin daha fazla alaycı mizahı kullandıklarını ileri sürmektedirler. Mizah tarzlarının diğer alt boyutlar ile yaş arasındaki varyans analizi sonuçları incelendiğinde, üretici-sosyal mizahta [F(3$267)=.15 \mathrm{p}>.05]$, onaylayıc1 mizahta $[F(3-279)=1.07 \mathrm{p}>.05]$, reddedici mizahta $[F(3-278)=.67$ $\mathrm{p}>.05]$ ve mizahi olmayan tarz da ise $[F(3-296)=1.02 \mathrm{p}>.05]$ anlamlı bir farkl1lık bulunamamıştır. Başka bir anlatımla, öğretmenlerin yaşları ilerledikçe okul yöneticilerinin daha fazla alaycı mizah tarzını kullandıklarını ileri sürmüş ve üretici-sosyal, reddedici, mizahi olmayan ve stres arasında yaşa göre anlamlı bir farklı bulunmamıştır. Öğretmenlerin kıdemleri ile okul yöneticilerinin mizah tarzları ve strese ilişkin dağ 1 lım Tablo 7' de verilmiştir. 
Tablo 7

Öğretmenlerin Kıdemleri ile Okul Yöneticilerinin Mizah Tarzları ve Strese İlişkin ANOVA

\begin{tabular}{|c|c|c|c|c|c|c|c|c|}
\hline Boyutlar & $Y_{l l}$ & $n$ & $\bar{X}$ & $S$ & $s d$ & $F$ & $p>05$ & Scheffe \\
\hline \multirow{4}{*}{ Alaycı } & $1-10$ & 48 & 1.33 & .63 & 3 & \multirow{4}{*}{2.09} & \multirow{4}{*}{.10} & \multirow{4}{*}{ - } \\
\hline & $11-20$ & 82 & 1.45 & .83 & 274 & & & \\
\hline & $21-30$ & 109 & 1.69 & 1.03 & 277 & & & \\
\hline & $31+$ & 39 & 1.52 & .94 & & & & \\
\hline \multirow{4}{*}{ Üretici sosyal } & $1-10$ & 48 & 2.40 & .75 & 3 & \multirow{4}{*}{.03} & \multirow{4}{*}{.99} & \multirow{4}{*}{ - } \\
\hline & $11-20$ & 78 & 2.43 & .93 & 263 & & & \\
\hline & $21-30$ & 105 & 2.39 & .83 & 266 & & & \\
\hline & $31+$ & 36 & 2.42 & .91 & & & & \\
\hline \multirow{4}{*}{ Onaylayıcı } & $1-10$ & 47 & 3.57 & .92 & 3 & \multirow{4}{*}{1.59} & \multirow{4}{*}{.19} & \multirow{4}{*}{-} \\
\hline & $11-20$ & 84 & 3.20 & 1.01 & 274 & & & \\
\hline & $21-30$ & 111 & 3.21 & 1.05 & 277 & & & \\
\hline & $31+$ & 37 & 3.25 & .94 & & & & \\
\hline \multirow{4}{*}{ Reddedici } & $1-10$ & 49 & 1.93 & .59 & 3 & \multirow{4}{*}{.22} & \multirow{4}{*}{.88} & \multirow{4}{*}{-} \\
\hline & $11-20$ & 84 & 2.01 & .69 & 274 & & & \\
\hline & $21-30$ & 108 & 2.00 & .72 & 277 & & & \\
\hline & $31+$ & 37 & 2.05 & .83 & & & & \\
\hline \multirow{4}{*}{$\begin{array}{l}\text { Mizahi } \\
\text { Olmayan }\end{array}$} & $1-10$ & 49 & 2.07 & 1.04 & 3 & \multirow{4}{*}{1.32} & \multirow{4}{*}{.26} & \multirow{4}{*}{-} \\
\hline & $11-20$ & 89 & 2.44 & 1.09 & 292 & & & \\
\hline & $21-30$ & 118 & 2.35 & 1.05 & 295 & & & \\
\hline & $31+$ & 40 & 2.25 & 1.10 & & & & \\
\hline \multirow{4}{*}{ Stres } & $1-10$ & 42 & 2.81 & .38 & 3 & \multirow{4}{*}{.71} & \multirow{4}{*}{.54} & \multirow{4}{*}{-} \\
\hline & $11-20$ & 80 & 2.82 & .61 & 250 & & & \\
\hline & $21-30$ & 100 & 2.71 & .51 & 253 & & & \\
\hline & $31+$ & 32 & 2.77 & .57 & & & & \\
\hline
\end{tabular}

Tablo 7' de verilen öğretmenlerin kıdemleri ile okul yöneticilerinin mizah tarzları ve strese ilişkin dağılım incelendiğinde; 21-30 y1l ( $\bar{X}=1.69)$ ve 31 ve üzeri y1l $(\bar{X}=1.52)$ kıdeme sahip öğretmenler, hiç düzeyinde diğer kıdeme sahip olanlara göre okul yöneticilerinin daha fazla alaycı mizah tarzını kullandıklarını ileri sürmektedir. Diğer mizah tarzlarında ise, 11-20 yıl $(\overline{\mathrm{X}}=2,43)$ arasında olanlar yöneticilerin, üretici-sosyal mizahı, 1-10 yıl ( $\overline{\mathrm{X}}=3.57)$ arasında olanlar onaylayıcı mizahı, 31 ve üzeri yıl $(\overline{\mathrm{X}}=2.05)$ arasında olanlar reddedici mizahı, 11-20 yıl ( $\overline{\mathrm{X}}=2.44)$ arasında kıdeme sahip olanlar mizahi olmayan tarzı kullandıklarını düşünmektedir. Öğretmenlerin stres yaşama düzeyleri incelendiğinde ise, 11-20 yıl $(\overline{\mathrm{X}}=2.82)$ arasındaki olan öğretmenlerde orta düzeyinde stres yaşadıkları anlaşılmaktadır. Standart sapma değerleri incelendiğinde; en homojen değerlendirmeyi alaycı mizahta $S=.63$ 1-10 yıl grubunda, üretici-sosyal mizahta $S=, 75$ 1-10 y1l grubunda, onaylayıcı mizahta $S=.92$ 1-10 y1l grubunda, reddedici mizahta $S=.59$ 1-10 y1l grubunda, mizahi olmayan tarz da ise $S=1,04$ 1-10 yıl arasında kıdeme sahip öğretmenler oluşturmaktadır. Öğretmenlerin kıdemleri ile okul yöneticilerinin mizah tarzları arasındaki varyans incelediğinde; alaycı mizahta $[F(3-274)=2.09 \mathrm{p}>.05]$, üretici-sosyal mizah $[F(3-263)=.03 \mathrm{p}>.05]$, onaylayıc1 mizah $[F(3-274)=1.59 \mathrm{p}>.05]$, reddedici mizah $[F(3-274)=.22 \mathrm{p}>.05]$ ve mizahi olmayan tarzda ise $[F(3-292)=1.32 \mathrm{p}>.05]$ anlamlı bir farklılık bulunamamıştır. Başka bir anlatımla, öğretmenlerin 
kıdemleri ile okul yöneticilerinin kullandıkları mizah tarzları ve stres arasında anlamlı bir farklılık bulunmamaktadır. Öğretmenlerin branşları ile okul yöneticilerinin mizah tarzları ve strese ilişkin dağılım Tablo 8' de verilmiştir:

Tablo 8

Öğretmenlerin Branşları ile Okul Yöneticilerinin Mizah Tarzları ve Strese İlişkin ANOVA

\begin{tabular}{|c|c|c|c|c|c|c|c|c|}
\hline Boyutlar & Branş & $n$ & $\bar{X}$ & $S$ & $s d$ & $F$ & $p>05$ & Scheffe \\
\hline \multirow{6}{*}{ Alaycı } & Sinif & 209 & 1.53 & .88 & \multirow{6}{*}{$\begin{array}{c}5 \\
274 \\
279\end{array}$} & \multirow{6}{*}{.25} & \multirow{6}{*}{.94} & \multirow[t]{6}{*}{ 政 } \\
\hline & Okul Öncesi & 24 & 1.56 & 1.17 & & & & \\
\hline & Beden E. & 2 & 1.58 & .82 & & & & \\
\hline & Y. Dil & 10 & 1.70 & 1.20 & & & & \\
\hline & Din Kült. & 5 & 1.16 & .28 & & & & \\
\hline & Diğer & 30 & 1.60 & .94 & & & & \\
\hline \multirow{6}{*}{$\begin{array}{l}\text { Üretici } \\
\text { sosyal }\end{array}$} & Sinif & 205 & 2.40 & .87 & \multirow{6}{*}{$\begin{array}{c}5 \\
264 \\
269\end{array}$} & \multirow{6}{*}{.61} & \multirow{6}{*}{.68} & \multirow{6}{*}{-} \\
\hline & Okul Öncesi & 22 & 2.53 & .90 & & & & \\
\hline & Beden E. & 2 & 1.62 & .53 & & & & \\
\hline & Y. Dil & 11 & 2.17 & .54 & & & & \\
\hline & Din Kül. & 3 & 2.29 & .38 & & & & \\
\hline & Diğer & 27 & 2.35 & .85 & & & & \\
\hline \multirow{6}{*}{ Onaylayıcı } & Sinif & 213 & 3.23 & 1.01 & \multirow{6}{*}{$\begin{array}{c}5 \\
275 \\
280\end{array}$} & \multirow{6}{*}{2.66} & \multirow{6}{*}{$.22 *$} & \multirow{6}{*}{$2-1,3,5,6$} \\
\hline & Okul Öncesi & 23 & 3.89 & 1.05 & & & & \\
\hline & Beden E. & 2 & 2.50 & .42 & & & & \\
\hline & Y. Dil & 11 & 2.76 & .74 & & & & \\
\hline & Din Kült. & 4 & 3.40 & 1.01 & & & & \\
\hline & Diğer & 28 & 3.22 & .93 & & & & \\
\hline \multirow{6}{*}{ Reddedici } & Sinif & 210 & 1.98 & .70 & \multirow{6}{*}{$\begin{array}{c}5 \\
274 \\
279\end{array}$} & \multirow{6}{*}{.85} & \multirow{6}{*}{.50} & \multirow{6}{*}{-} \\
\hline & Okul Öncesi & 23 & 1.98 & .72 & & & & \\
\hline & Beden E. & 2 & 2.70 & .14 & & & & \\
\hline & Y. Dil & 11 & 2.10 & 1.07 & & & & \\
\hline & Din Kült. & 5 & 1.60 & .24 & & & & \\
\hline & Diğer & 29 & 2.09 & .72 & & & & \\
\hline \multirow{6}{*}{$\begin{array}{l}\text { Mizahi } \\
\text { Olmayan }\end{array}$} & Sinıf & 224 & 2.29 & 1.02 & \multirow{6}{*}{$\begin{array}{c}5 \\
292 \\
297\end{array}$} & \multirow{6}{*}{1.95} & \multirow{6}{*}{.08} & \multirow{6}{*}{-} \\
\hline & Okul Öncesi & 25 & 2.22 & 1.21 & & & & \\
\hline & Beden E. & 2 & 4.33 & .94 & & & & \\
\hline & Y. Dil & 11 & 2.66 & 1.21 & & & & \\
\hline & Din Kült. & 5 & 2.33 & 1.05 & & & & \\
\hline & Diğer & 31 & 2.54 & 1.27 & & & & \\
\hline \multirow{6}{*}{ Stres } & Sinif & 196 & 2.75 & .51 & & & & \\
\hline & Okul Öncesi & 18 & 2.75 & .70 & & & & \\
\hline & Beden E. & 1 & 2.85 & . & 233 & 1.28 & .27 & - \\
\hline & Y. Dil & 7 & 3.15 & .35 & & & & \\
\hline & Din Kül. & 5 & 3.21 & .81 & & & & \\
\hline & Diğer & 29 & 2.77 & .52 & & & & \\
\hline
\end{tabular}

Tablo 8' de verilen öğretmenlerin branşları ile okul yöneticilerinin mizah tarzları ve strese ilişkin görüşleri dağılım incelendiğinde; okul öncesi öğretmenlerine göre okul yöneticileri onaylayıcı mizahı $(\overline{\mathrm{X}}=3.89)$ çok düzeyinde, üretici-sosyal mizahı $(\overline{\mathrm{X}}=2.53)$ orta düzeyinde, alaycı mizahı $(\overline{\mathrm{X}}=1.70)$ hiç düzeyinde, reddedici mizahı $(\overline{\mathrm{X}}=2.70)$ orta düzeyinde ve mizahi olmayan tarzı ise $(\bar{X}=4.33)$ tam düzeyinde kullanmaktadır. Stres yaşama düzeyleri incelendiğinde ise, stres yaşama düzeylerinin en yüksek ( $\bar{X}=3.21)$ din kültürü branşında, en düşük ( $\bar{X}=3.21)$ ise sinıf ve okul öncesi branşlarında olduğu anlaşılmaktadır. Standart sapma değerleri incelendiğinde; en homojen 
değerlendirmeyi alaycı mizahta $S=.28$ din kültürü branşında, üretici-sosyal mizahta $S=.38$ din kültürü branşında, onaylayıcı mizah tarzında $S=.42$ beden eğitimi branşında, reddedici mizah tarzında $S=.14$ beden eğitimi branşında, mizahi olmayan tarz da ise $S=.94$ beden eğitimi branşındaki öğretmenler oluşturmaktadır. Öğretmenlerin branşları ile okul yöneticilerinin mizah tarzları arasındaki varyans incelediğinde; onaylayıcı mizahta $[F(5-275)=2.66 \mathrm{p}<.05]$ anlamlı bir farklılık vardır. Mizahın diğer boyutları ile branşlar arasındaki varyans incelendiğinde; alaycı mizah $[F(5-274)=.25 \mathrm{p}>.05]$, üreticisosyal mizah $[F(5-264)=.68 \mathrm{p}>.05]$, reddedici mizah $[F(5-274)=.50 \mathrm{p}>.05]$, mizahi olmayan tarzda $[F(5-292)=.08 \mathrm{p}>05]$ ve stres yaşamalarında $[F(5-233)=1.28 \mathrm{p}>.05]$ anlamlı bir farkl1lık bulunamamıştır. Başka bir anlatımla, onaylayıcı mizah tarzında okul öncesi öğretmenler ile diğer branştaki öğretmenlerin görüşleri ve stres arasında anlamlı bir farklılık bulurken, diğer mizah tarzları ve stres arasında anlamlı bir fark bulunamamıştır. Öğretmenlerin medeni durumları ile okul yöneticilerinin mizah tarzları ve strese ilişkin dağılım Tablo 9' da verilmiştir.

Tablo 9

Öğretmenlerin Medeni Durumları ile Okul Yöneticilerinin Mizah Tarzları ve Strese İlişkin ANOVA

\begin{tabular}{|c|c|c|c|c|c|c|c|c|}
\hline Boyutlar & Medeni Durum & $n$ & $\bar{X}$ & $S$ & $s d$ & $F$ & $p>05$ & Scheffe \\
\hline \multirow{3}{*}{ Alaycı } & Evli & 252 & 1.51 & .89 & 2 & \multirow{3}{*}{7.00} & \multirow{3}{*}{$.00 *$} & \multirow{3}{*}{$\begin{array}{l}1-3 \\
2-3\end{array}$} \\
\hline & Bekar & 19 & 1.35 & .62 & 278 & & & \\
\hline & Dul/Boşanmış & 10 & 2.56 & 1.44 & 280 & & & \\
\hline \multirow{3}{*}{ Üretici sosyal } & Evli & 241 & 2.40 & .85 & 2 & \multirow{3}{*}{1.16} & \multirow{3}{*}{.31} & \multirow{3}{*}{-} \\
\hline & Bekar & 19 & 2.18 & 1.03 & 267 & & & \\
\hline & Dul/Boşanmış & 10 & 2.68 & .54 & 269 & & & \\
\hline \multirow{3}{*}{ Onaylayıcı } & Evli & 250 & 3.30 & .99 & 2 & \multirow{3}{*}{1.44} & \multirow{3}{*}{.23} & \multirow{3}{*}{-} \\
\hline & Bekar & 20 & 3.19 & 1.30 & 279 & & & \\
\hline & Dul/Boşanmış & 12 & 2.80 & .96 & 281 & & & \\
\hline \multirow{3}{*}{ Reddedici } & Evli & 251 & 1.98 & .70 & 2 & \multirow{3}{*}{3.92} & \multirow{3}{*}{$.02 *$} & \multirow{3}{*}{$\begin{array}{l}1-3 \\
2-3\end{array}$} \\
\hline & Bekar & 20 & 1.88 & .50 & 278 & & & \\
\hline & Dul/Boşanmış & 10 & 2.60 & 1.00 & 280 & & & \\
\hline \multirow{3}{*}{$\begin{array}{l}\text { Mizahi } \\
\text { Olmayan }\end{array}$} & Evli & 266 & 2.31 & 1.06 & 2 & \multirow{3}{*}{1.79} & \multirow{3}{*}{.16} & \multirow{3}{*}{-} \\
\hline & Bekar & 21 & 2.28 & 1.34 & 296 & & & \\
\hline & Dul/Boşanmış & 12 & 2.91 & 1.01 & 298 & & & \\
\hline \multirow{3}{*}{ Stres } & Evli & 227 & 2.76 & .53 & 2 & \multirow{3}{*}{.55} & \multirow{3}{*}{.57} & \multirow{3}{*}{-} \\
\hline & Bekar & 18 & 2.89 & .49 & 253 & & & \\
\hline & Dul/Boşanmış & 11 & 2.82 & .72 & 255 & & & \\
\hline
\end{tabular}

Tablo 9' da verilen öğretmenlerin medeni durumları ile okul yöneticilerinin mizah tarzları ve strese ilişkin görüşlerine ilişkin veriler incelendiğinde; dul veya boşanmış $(\overline{\mathrm{X}}=2.56)$ öğretmenler, az düzeyinde okul yöneticilerinin daha fazla alaycı mizah tarzını kullandıklarını ileri sürmektedir. Diğer mizah tarzlarında ise, dul veya boşanmış $(\overline{\mathrm{X}}=2.68)$ öğretmenler üretici-sosyal mizahı, evli $(\overline{\mathrm{X}}=3.30)$ olanlar onaylayıcı mizahı, dul veya boşanmış $(\overline{\mathrm{X}}=2.60)$ olanlar reddedici mizahı ve dul veya boşanmış $(\bar{X}=2.91)$ olanlar ise mizahi olmayan tarzı kullandıklarını ileri sürmektedir. Stres yaşama düzeyleri incelendiğinde ise, bekar $(\overline{\mathrm{X}}=2.89)$ öğretmenlerin orta düzeyinde stres yaşadıkları saptanmaktadır. Standart sapma değerleri incelendiğinde; en homojen değerlendirmeyi alaycı mizah tarzında $S=.62$ bekar öğretmenlere a, üretici-sosyal mizahta $S=.54$ dul veya boşanmış öğretmenler, 
onaylayıcı mizahta $S=.96$ dul veya boşanmış öğretmenler, reddedici mizahta $S=.50$ bekar öğretmenler, mizahi olmayan tarz da ise $S=1.01$ dul veya boşanmış öğretmenler oluşturmaktadır. Öğretmenlerin medeni durumları ile okul yöneticilerinin mizah tarzları arasındaki varyans incelendiğinde; alaycı mizah $[F(2-278)=7.00 \mathrm{p}<.05]$ ve reddedici mizah tarzında $[F(2-278)=3.92$ $\mathrm{p}<.05]$ medeni duruma göre anlamlı bir farklılık bulunmaktadır. Farklılığın hangi gruplar arasında olduğunu saptamak amacıyla hesaplanan scheffe testine göre alaycı mizahta evli-dul ve bekar-dul öğretmenler arasında, reddedici mizahta evli-dul ve bekar-dul öğretmenler arasında olduğu anlaşılmaktadır. Mizah tarzlarının diğer alt boyutları ile medeni durum arasındaki varyans analizi incelendiğinde; üretici-sosyal mizahta $[F(2-267)=1.16 \mathrm{p}>05]$, onaylayıcı mizahta $[F(2-279)=1.44$ p>.05] ve mizahi olmayan tarzda $[F(2-236)=3.97$ p >.05] anlamlı bir farklılık bulunamamıştır. Başka bir anlatımla, dul veya boşanmış öğretmenler okul yöneticilerinin daha fazla alaycı ve reddedici mizah tarzını kullandıklarını ileri sürerken; üretici-sosyal, onaylayıcı, mizahi olmayan tarz ve stres arasında medeni duruma göre anlamlı bir farklılık bulunmamaktadır. Öğretmenlerin mesleklerini sevme durumları ile okul yöneticilerinin mizah tarzları ve strese ilişkin dağılım Tablo 10' da verilmiştir.

Tablo 10

Öğretmenlerin Mesleklerini Sevme Durumları ile Okul Yöneticilerinin Mizah Tarzları ve Strese İlişkin ANOVA

\begin{tabular}{|c|c|c|c|c|c|c|c|c|}
\hline Boyutlar & Meslek Sevgisi & $n$ & $\bar{X}$ & $S$ & $s d$ & $F$ & $p>05$ & Scheffe \\
\hline \multirow{5}{*}{ Alaycı } & Hiç & 3 & 1.22 & .25 & \multirow{5}{*}{$\begin{array}{c}4 \\
276 \\
280\end{array}$} & \multirow{5}{*}{.94} & \multirow{5}{*}{.43} & \multirow{5}{*}{-} \\
\hline & $\mathrm{Az}$ & 4 & 1.79 & 1.14 & & & & \\
\hline & Orta & 33 & 1.80 & .98 & & & & \\
\hline & Çok & 127 & 1.51 & .91 & & & & \\
\hline & Tam & 114 & 1.49 & .90 & & & & \\
\hline \multirow{5}{*}{ Üretici sosyal } & Hiç & 3 & 2.12 & .57 & \multirow{5}{*}{$\begin{array}{c}4 \\
265 \\
269\end{array}$} & \multirow{5}{*}{.48} & \multirow{5}{*}{.74} & \multirow{5}{*}{ - } \\
\hline & $\mathrm{Az}$ & 5 & 2.17 & 1.10 & & & & \\
\hline & Orta & 31 & 2.28 & .61 & & & & \\
\hline & Çok & 122 & 2.46 & .85 & & & & \\
\hline & Tam & 109 & 2.39 & .92 & & & & \\
\hline \multirow{5}{*}{ Onaylayıcı } & Hiç & 3 & 3.40 & .34 & \multirow{5}{*}{$\begin{array}{c}4 \\
278 \\
282\end{array}$} & \multirow{5}{*}{.86} & \multirow{5}{*}{.48} & \multirow{5}{*}{-} \\
\hline & $\mathrm{Az}$ & 5 & 2.92 & 1.11 & & & & \\
\hline & Orta & 31 & 3.04 & .72 & & & & \\
\hline & Çok & 129 & 3.36 & .99 & & & & \\
\hline & Tam & 115 & 3.23 & 1.11 & & & & \\
\hline \multirow{5}{*}{ Reddedici } & Hiç & 3 & 1.93 & .94 & \multirow{5}{*}{$\begin{array}{c}4 \\
277 \\
281\end{array}$} & \multirow{5}{*}{2.60} & \multirow{5}{*}{$.03^{*}$} & \multirow{5}{*}{$3-5$} \\
\hline & $\mathrm{Az}$ & 5 & 2.16 & .65 & & & & \\
\hline & Orta & 32 & 2.36 & .84 & & & & \\
\hline & Çok & 130 & 1.97 & .68 & & & & \\
\hline & Tam & 112 & 1.92 & .68 & & & & \\
\hline \multirow{4}{*}{ Mizahi Olmayan } & Hiç & 3 & 2.77 & 1.01 & \multirow{4}{*}{$\begin{array}{c}4 \\
294 \\
298\end{array}$} & \multirow{4}{*}{.94} & \multirow{4}{*}{.42} & \multirow{4}{*}{-} \\
\hline & $\mathrm{Az}$ & 5 & 1.66 & .78 & & & & \\
\hline & Orta & 33 & 2.50 & 1.02 & & & & \\
\hline & Çok & 137 & 2.26 & 1.06 & & & & \\
\hline
\end{tabular}




\begin{tabular}{|c|c|c|c|c|c|c|c|c|}
\hline & Tam & 121 & 2.36 & 1.12 & & & & \\
\hline \multirow{5}{*}{ Stres } & Hiç & 3 & 2.92 & .12 & \multirow[b]{2}{*}{4} & \multirow{5}{*}{3.64} & \multirow{5}{*}{$.00 *$} & \multirow{5}{*}{$4-5$} \\
\hline & $\mathrm{Az}$ & 4 & 2.82 & .66 & & & & \\
\hline & Orta & 27 & 2.94 & .51 & \multirow{3}{*}{$\begin{array}{l}235 \\
239\end{array}$} & & & \\
\hline & Çok & 118 & 2.85 & .52 & & & & \\
\hline & Tam & 105 & 2.62 & .53 & & & & \\
\hline
\end{tabular}

Tablo 10’ da verilen öğretmenlerin mesleklerini sevme durumu ile okul yöneticilerinin mizah tarzları ve strese ilişkin dağılım incelendiğinde; mesleğini orta düzeyde $(\overline{\mathrm{X}}=2.36)$ ve az düzeyde $(\overline{\mathrm{X}}=2.16)$ seven öğretmenler okul yöneticilerinin daha fazla reddedici mizah tarzını kullandıklarını ileri sürmektedir. Diğer mizah tarzlarında ise, mesleğini orta $(\bar{X}=1.80)$ düzeyde sevenler alayc1 mizahı, çok düzeyinde ( $\overline{\mathrm{X}}=2.46)$ sevenler üretici-sosyal mizahı, hiç düzeyinde $(\overline{\mathrm{X}}=3.40)$ sevenler onaylayıcı mizahı ve orta düzeyde $(\overline{\mathrm{X}}=11.92)$ sevenler ise okul yöneticilerinin mizahi olmayan tarzı kullandıklarını düşündükleri saptanmıştır. Stres yaşama düzeyleri incelendiğinde ise, mesleğini orta $(\bar{X}=2.94)$ düzeyde seven öğretmenlerin orta düzeyinde stres yaşadıkları anlaşılmaktadır. Standart sapma değerleri incelendiğinde; en homojen değerlendirmeyi alaycı mizah tarzında $S=.25$ mesleğini hiç sevmeyen öğretmenler, üretici-sosyal mizah tarzında $S=.57$ mesleğini hiç sevmeyenler, onaylayıcı mizah tarzında $S=.34$ hiç sevmeyenler, reddedici mizah tarzında $S=.65$ az sevenler, mizahi olmayan tarz da ise $\mathrm{S}=.78$ mesleğini az seven öğretmenler oluşturmaktadır. Öğretmenlerin mesleklerini sevme durumu ile okul yöneticilerinin mizah tarzları arasındaki varyans analizi incelendiğinde; reddedici mizah tarzında $[F(4-277)=2.60 \mathrm{p}<.05]$ ve streste $[F(4-235)=3.64 \mathrm{p}<.05]$ anlamlı bir farklılık bulunmaktadır. Farklılığın hangi gruplar arasında olduğunu saptamak amaciyla hesaplanan Scheffe testine göre; reddedici mizahta orta-tam arasında, streste ise, çok-tam arasında olduğu anlaşılmaktadır. Mizah tarzlarının diğer alt boyutları ile medeni durum arasındaki varyans analizi incelendiğinde; alaycı mizahta $[F(4-276)=.94$ p >.05], üretici-sosyal mizahta $[F(4-265)=.48$ $\mathrm{p}>.05]$, onaylayıcı mizah tarzında $[F(4-276)=.86 \mathrm{p}>.05]$ ve mizahi olmayan tarzda ise $[F(4-294)=$ $.94 \mathrm{p}>05$ ] anlamlı bir farklılık bulunamamıştır. Başka bir anlatımla, mesleğini orta düzeyde seven öğretmenler okul yöneticilerinin daha fazla reddedici mizah tarzını kullandıklarını ileri sürerken, alaycı, üretici-sosyal, onaylayıcı ve mizahi olmayan tarz arasında öğretmenlerin mesleklerini sevme durumuna göre anlamlı bir farklılık bulunmamaktadır. Öğretmenlerin sosyo-ekonomik durumları ile okul yöneticilerinin mizah tarzları ve strese dağılım Tablo 11' de verilmiştir. 
Tablo 11

Öğretmenlerin Sosyo-Ekonomik Durumları İle Okul Yöneticilerinin Mizah Tarzları ve Strese İlişkin ANOVA

\begin{tabular}{|c|c|c|c|c|c|c|c|c|}
\hline Boyutlar & $\begin{array}{c}\text { Sosyo- } \\
\text { Ekonomik } \\
\text { Durum }\end{array}$ & $n$ & $\bar{X}$ & $S$ & $s d$ & $F$ & $p>05$ & Scheffe \\
\hline \multirow{3}{*}{ Alaycı } & Düşük & 13 & 1.67 & .89 & 2 & \multirow{3}{*}{1.64} & \multirow{3}{*}{.49} & \multirow{3}{*}{-} \\
\hline & Orta & 235 & 1.49 & .86 & 279 & & & \\
\hline & Yüksek & 34 & 1.78 & 1.21 & 281 & & & \\
\hline \multirow{3}{*}{$\begin{array}{l}\text { Üretici } \\
\text { sosyal }\end{array}$} & Düşük & 14 & 2.93 & .73 & 2 & \multirow{3}{*}{2.88} & \multirow{3}{*}{.05} & \multirow{3}{*}{-} \\
\hline & Orta & 220 & 2.37 & .84 & 262 & & & \\
\hline & Yüksek & 36 & 2.40 & .93 & 269 & & & \\
\hline \multirow{3}{*}{ Onaylayıcı } & Düşük & 13 & 3.47 & .88 & 2 & \multirow{3}{*}{1.04} & \multirow{3}{*}{.35} & \multirow{3}{*}{-} \\
\hline & Orta & 233 & 3.29 & .99 & 279 & & & \\
\hline & Yüksek & 36 & 3.06 & 1.19 & 281 & & & \\
\hline \multirow{3}{*}{ Reddedici } & Düşük & 13 & 2.00 & .63 & 2 & \multirow{3}{*}{1.64} & \multirow{3}{*}{.19} & \multirow{3}{*}{-} \\
\hline & Orta & 231 & 1.97 & .68 & 278 & & & \\
\hline & Yüksek & 37 & 2.20 & .91 & 280 & & & \\
\hline \multirow{3}{*}{$\begin{array}{l}\text { Mizahi } \\
\text { Olmayan }\end{array}$} & Düşük & 14 & 2.33 & .83 & 2 & \multirow{3}{*}{.00} & \multirow{3}{*}{.99} & \multirow{3}{*}{-} \\
\hline & Orta & 247 & 2.33 & 1.09 & 296 & & & \\
\hline & Yüksek & 38 & 2.31 & 1.14 & 298 & & & \\
\hline \multirow{3}{*}{ Stres } & Düşük & 12 & 2.77 & .57 & 2 & \multirow{3}{*}{.05} & \multirow{3}{*}{.94} & \multirow{3}{*}{-} \\
\hline & Orta & 214 & 2.76 & .52 & 254 & & & \\
\hline & Yüksek & 31 & 2.81 & .61 & 256 & & & \\
\hline
\end{tabular}

Tablo 11' de verilen öğretmenlerin sosyo-ekonomik durumları ile okul yöneticilerinin mizah tarzları ve strese ilişkin dağılım incelendiğinde; düşük $(\overline{\mathrm{X}}=2.93)$ ve yüksek $(\overline{\mathrm{X}}=2.40)$ gelir seviyesine sahip öğretmenler, orta düzeyinde diğer gelir seviyesine sahip olanlara göre okul yöneticilerinin daha fazla üretici-sosyal mizah tarzını kullandıkları ileri sürmektedir. Diğer mizah tarzlarında ise, yüksek $(\overline{\mathrm{X}}=1.78)$ gelir seviyesinde olanlar alayc1 mizahı, orta $(\overline{\mathrm{X}}=3.29)$ gelir seviyesinde olanlar onaylayıc1 mizahı, yüksek $(\bar{X}=2.20)$ gelir seviyesinde olanlar reddedici mizahı, orta ve düşük $(\bar{X}=2.33)$ gelir seviyesine sahip olan öğretmenler ise okul yöneticilerinin daha fazla mizahi olmayan tarzı kullandıklarını düşünmektedir. Stres yaşama düzeyleri incelendiğinde ise, yüksek $(\bar{X}=2.81)$ gelir seviyesine sahip olan öğretmenlerin orta düzeyinde stres yaşadıkları saptanmıştır. Standart sapma değerleri incelendiğinde; en homojen değerlendirmeyi alaycı mizahta $S=.86$ yüksek gelir grubunda, üretici-sosyal mizahta $S=.73$ düşük gelir grubunda, onaylayıcı mizahta $S=.88$ düşük gelir grubunda, reddedici mizahta $\mathrm{S}=.63$ düşük gelir grubunda, mizahi olmayan tarzda ise $\mathrm{S}=.83$ düşük gelir grubundaki öğretmenler oluşturmaktadır. Öğretmenlerin sosyo-ekonomik durumları ile okul yöneticilerinin mizah tarzları arasındaki varyans incelendiğinde; alaycı $[F(2-279)=1.64 \mathrm{p}>.05]$, üretici-sosyal $[F(2-262)=2.88 \mathrm{p}>.05]$, onaylayıc1 $[F(2-279)=1,04 \mathrm{p}>.05]$, reddedici $[F(2-278)=$ $1,64 \mathrm{p}>.05]$ ve mizahi olmayan tarzda $[F(2-296)=0,00 \mathrm{p}>.05]$ anlamlı bir fark bulunamamıştır. Başka bir anlatımla, öğretmenlerin sosyo-ekonomik düzeyleri ile okul yöneticilerinin kullandıkları mizah tarzları ve stres arasında anlamlı bir fark bulunmamaktadır. Öğretmenlerin mesleği bırakma durumları ile okul yöneticilerinin mizah tarzları ve stres dağılım Tablo 12' de verilmiştir: 
Tablo 12

Öğretmenlerin Mesleği Bırakma Durumları ile Okul Yöneticilerinin Mizah Tarzları ve Strese İlişkin t-Testi

\begin{tabular}{|c|c|c|c|c|c|c|c|}
\hline Mizah Boyutlart & Tercih & $n$ & $\bar{X}$ & $S$ & $s d$ & $t$ & $P<.05$ \\
\hline \multirow[t]{2}{*}{ Alayc1 } & Hayır & 198 & 1.46 & .85 & 277 & 2.15 & $.03^{*}$ \\
\hline & Evet & 81 & 1.74 & 1.03 & & & \\
\hline \multirow{2}{*}{ Üretici sosyal } & Hayır & 189 & 2.42 & .90 & 267 & 0.59 & .55 \\
\hline & Evet & 80 & 2.35 & .75 & & & \\
\hline \multirow{2}{*}{ Onaylayıcı } & Hayır & 198 & 3.32 & 1.07 & 278 & 1.69 & .09 \\
\hline & Evet & 82 & 3.11 & .87 & & & \\
\hline \multirow[t]{2}{*}{ Reddedici } & Hayır & 199 & 1.92 & .65 & 278 & 2.54 & $.01 *$ \\
\hline & Evet & 81 & 2.18 & .82 & & & \\
\hline \multirow[t]{2}{*}{ Mizahi Olmayan } & Hayır & 211 & 2.25 & 1.09 & 295 & 1.90 & .05 \\
\hline & Evet & 86 & 2.52 & 1.06 & & & \\
\hline \multirow[t]{2}{*}{ Stres } & Hayır & 181 & 2.69 & .51 & 253 & 3.55 & $.00 *$ \\
\hline & Evet & 74 & 2.95 & .55 & & & \\
\hline
\end{tabular}

Tablo 12' de verilen öğretmenlerin mesleği bırakma durumları ile okul yöneticilerinin mizah tarzları arasındaki fark için hesaplanan t-testi dağılımı incelendiğinde; öğretmenlik mesleğini bırakmayı düşünmeyen ve düşünen öğretmenler, okul yöneticilerinin en fazla $(\bar{X}=1.92)$ ve $(\bar{X}=2.18)$ az düzeyinde reddedici mizahı kullandıklarını ileri sürerken, en az $(\bar{X}=2.35)$ ve $(\bar{X}=2.42)$ az düzeyinde üretici-sosyal mizahı kullandıklarını ileri sürmektedir. Standart sapma incelendiğinde, en homojen değerlendirmeyi streste mesleği bırakmayı düşünmeyen öğretmenler $\mathrm{S}=.51$ yaparken, en heterojen değerlendirmeyi ise mizahi olmayan tarzda yine mesleği bırakmayı düşünmeyen $S=1.09$ öğretmenlerin yaptıkları ortaya konmuştur. Öğretmenlerin mesleklerinin bırakma durumu ile okul yöneticilerinin kullandıkları mizah tarzları arasında alayc1 $[t(277)=2.15 \mathrm{p}<.05]$, reddedici $[t(278)$ $=2.54 \mathrm{p}<.05]$ ve stres $[t(253)=3.55 \mathrm{p}<.05]$ arasında anlamlı bir farklılık varken; üretici-sosyal $[\mathrm{t}$ $(267)=.59 \mathrm{p}>.05]$, onaylayıc1 $[t(278)=1.69 \mathrm{p}>05]$ ve mizahi olmayan $[t(295)=1.90 \mathrm{p}<>05]$ tarzda anlamlı bir fark bulunamamıştır. Başka bir anlatımla, mesleği bırakmayı düşünen öğretmenler okul yöneticilerinin daha fazla alaycı ve reddedici mizahı kullandıkları ve öğretmenlerin stres altında bulundukları sonucuna ulaşılmıştır. Alaycı ve reddedici mizahta anlamlı bir farklılık vardır.

\section{TARTIŞMA VE SONUÇ}

Öğretmenlerin algılarına göre, ilkokul yöneticilerinin mizah tarzlarının nasıl olduğuna ilişkin bulgular incelendiğinde; ilkokul yöneticilerinin onaylayıcı mizah tarzını daha fazla kullandıkları, en az düzeyde ise alaycı mizahı kullandıkları ortaya konmuştur. Onaylayıcı mizahın en çok kullanılan tarz olduğu bulgusu, literatürde daha önce yapılan bazı çalışmaların sonuçlarıyla benzerlik gösterirken (Kent, 1993; Koonce, 1997; Mertz, 2000; Özdemir ve Recepoğlu, 2010; Recepoğlu ve Özdemir, 2012; Philips, 2000; Puderbaugh, 2006; Recepoğlu, 2011; Recepoğlu, 2015; Spurgeon, 1998; Williams, 1994; Yerlikaya, 2009; Y1lmaz, 2011), okul yöneticilerinin onaylayıcı mizahtan farklı bir mizah tarzını daha çok kullandıklarını bulgulayan bazı araştırma sonuçlarıyla (Romero ve Arendt, 2011; Cemaloğlu vd., 2014) farklılaşmaktadır. Bu farklılık; seçilen örneklemin özelliklerinden, eğitim kademesinin çeşidinden ve kullanılan ölçeklerin türünden kaynaklanabilir. 
Sürekli gelişim ve değişimlere açık olan okullarda yöneticilerin onaylayıcı mizah tarzını daha çok sergilemeleri istenilen bir durumdur. Örgütsel yaşam açısından değerlendirildiğinde okul yöneticilerinin uyumlu/olumlu tarzlardan biri olan onaylayıcı mizaha sahip olmaları oldukça önemlidir. Sürekli olarak öğretmen, öğrenci ve velilerle yoğun bir iletişim halinde bulunan okul müdürleri, okul ikliminin oluşturulmasında ve okuldaki kararların alınmasında kilit rol oynayıcı kişilerdir. Yöneticilerin mizahı kullanılması, kullanılış şekline göre okulun iklimine, çalışanların motivasyonu ve verimliliğine, üretkenliğe ve ortak hedeflerin gerçekleştirilmesine doğrudan veya dolaylı olarak etki etmektedir. Onaylayıcı mizah tarzının mizaha karşı olumlu bir tutum geliştirmeyi ifade eden özelliği, gerek kişilerarası iletişim gerekse örgütsel iletişim açısından oldukça önemlidir. Bu bağlamda, okul yöneticilerinin sahip oldukları mizah tarzının örgütsel ortamda önemli bir etken olduğu ifade edilebilir.

Araştırmanın diğer bir bulgusu olan alaycı mizahın en az düzeyde algılanması, bazı araştırma bulgularıyla (Cemaloğlu, vd., 2014; Özdemir vd., 2011, Romero ve Arendt, 2011; Y1lmaz, 2011) desteklenirken, en az algılanan tarzın alaycı mizah olmadığı yönünde pek çok araştırma (Kent, 2003; Williams, 1994, Koonce, 1997; Mertz, 2000; Özdemir ve Recepoğlu, 2010; Özdemir ve Recepoğlu, 2012; Philips, 2000; Puderbaugh, 2006; Recepoğlu, 2011; Spurgeon, 1998) mevcuttur. Okul yöneticilerinin alaycı mizahı en az düzeyde kullanmaları onaylayıcı mizahın olumlu sonuçlarını arttırabilir. Mizaha karşı negatif bir tutum içeren uyumlu/olumlu mizah tarzlarından biri olan alaycı mizaha sıklıkla başvuran okul yöneticilerinin okullarında, sağlıksız bir iklimin hakim olacağı ileri sürülebilir. Öğretmenlerin bu türdeki bir mizah tarzına sıklıkla maruz kalmaları, olumsuz mizah tarzının bireysel, örgütsel veya örgüt dışı stres kaynağı olabileceği ifade edilebilir. Alaycı mizah tarzının başkalarını aşağılamak, küçük düşürmek, incitmek, başkaları üzerinde baskı kurarak kendisini daha üstün göstermek için başvurulan mizah tarzı olduğu düşünüldüğünde, yöneticilerin bu mizahi tarzı kullanmaları halinde okullarda çatışma ve gerginlik artarken kişilerarası iletişim zayıflayabilir. Alaycı mizah tarzına başvuran okul yöneticileri, bu tarz mizahı öğrenci, öğretmen, veli veya diğer personelle alay etmek için bir araç olarak kullanır. Karşıdakini incitecek olsalar bile aklına gelen komik şeyleri hiç çekinmeden söyleyebilir. Sevmediği bireyler hakkında alaycı ve saldırgan bir dille espriler yaparak onları rencide eder. Mizahi yönü olduğunu düşündügü bireylere de mizah yoluyla saldırır. Çalışanların eksikleri ile dalga geçer. Bu tür yöneticilerin bulundukları ortamlarda işbirliği, motivasyon, örgütsel bağlılık ve sağlıklı bir okul iklimi gelişemez (Cemaloğlu, 2017).

Öğretmenlerin algılarına göre, okul yöneticilerinin mizah kullanma tarzları ile öğretmenlerin stres yaşama düzeyleri arasında anlamlı bir ilişkinin olup olmadığına ilişkin bulgular incelendiğinde; okul yöneticileri uyumsuz/olumsuz mizah tarzlarından olan alaycı ve reddedici mizahı kullandıklarında öğretmenlerin stres yaşama düzeyleri artarken, uyumlu/olumlu tarzlardan biri olan onaylayıcı mizahı kullandıklarında ise stres düzeyinin azaldığı ortaya konmuştur. Bu bulgu, 
literatürde önceden yapılmış diğer araştırmaların bulgularıyla paralellik göstermektedir (Abel, 2002; Çetinkaya ve Şener, 2016; Erikson ve Feldstein, 2007; Hampes, 2010; Kuiper, Grimshaw, Leite ve Kirsh, 2004; Kuiper ve Martin, 1998; Martin ve Lefcourt, 1983; Martin, 1996; Mauriello ve McConatha, 2007; Tümkaya, 2007). Okul yöneticilerinin alaycı ve reddedici mizah tarzlarının, öğretmenlerin stres düzeyi arasında düşük ve pozitif yönde anlamlı bir ilişkinin olduğu, onaylayıcı mizah tarzı ile stres arasında negatif yönlü, düşük ve anlamsız ilişkinin olduğu saptanmıştır. Üreticisosyal ve mizahi olmayan tarz ile stres arasında ise anlamlı bir farklılık bulunmamıştır. Mizaha karşı pozitif tutum içeren üretici-sosyal mizah tarzının diğer bir olumlu tarz olan onaylayıcı mizahtan farklı olarak stres ile anlamlı bir ilişkide olmadığı sonucunun bulgulanması, yapılan araştırmada ifade edilemeyen farklı değişkenlerden kaynaklanabilir. Mizahın iş yaşamında okul yöneticileri tarafından öğretmenlere yönelik kullanımı, olumlu veya olumsuz tarzda oluşuna göre algılanan stres düzeyinin de farklılık göstereceğini ortaya konulmuştur. Onaylayıcı mizah tarzının dışadönüklükle, olumlu duygularla, iyimserlikle ve sosyal uyumla pozitif yönde ilişkide olduğu, mizah tarzının sağlıklı ve stresle etkili başa çıkma tarzı ile pozitif (Erikson ve Feldstein, 2007), psikolojik olarak sağlıklı olma durumu ile pozitif (Martin, 2001) ve depresyon ve kaygı ile negatif (Kuiper, Grimshaw, Leite ve Kirsh, 2004) yönde ilişkili olduğu saptanmıştır. Olumlu bir mizah yeteneğine sahip bireylerde daha düşük düzeyde depresyon, endişe ve stres görüldügü sonucuna ulaşılarak bu çalışmanın bulgularını desteklenmektedir (Abel, 2002; Blase vd., 1986; Kuiper ve Martin, 1993; Kuiper ve Martin, 1998; Martin, 1996; Martin ve Lefcourt, 1983; Mauriello ve McConatha, 2007). Mizah, stresin algılanmasında önemli bir değişkendir.

Okul yöneticilerinin mizah kullanma tarzları öğretmenlerin stres yaşama düzeylerinin anlamlı bir yordayıcısı olup olmadığına ilişkin bulgular incelendiğinde; ilkokul yöneticilerinin öğretmenlere yönelik kullandıkları mizah tarzlarından üretici-sosyal mizah tarzının, öğretmenlerin stres yaşama düzeylerinin bir yordayıcısı olarak saptanmıştır. Bu bulgu, literatürde yapılan diğer çalışmaların bulgularıyla benzerlik gösterirken (Kazarian ve Martin, 2004; Martin vd., 2003; Özdemir vd., 2011; Recepoğlu ve Özdemir, 2012; Recepoğlu, 2008; Saroglou ve Scariot, 2002; Yerlikaya, 2003), mizahın stres üzerinde bir etkisinin olmadığı sonucunu ortaya koyan bazı araştırma bulgularıyla farkl1lık göstermektedir (Abel, 2002; Porterfield, 1987; Yerlikaya, 2009). Porterfield (1987) tarafından yapılan çalışmada, mizahın stres üzerinde etkili olmadığını; ancak depresyon ile ilişkili olduğu yordanmıştır. Yerlikaya'nın (2009) araştırmasına göre mizahın strese neden olan yaşam olayları ve olumsuz duygudurum arasındaki ilişkileri düzenleyen bir rolü olmadığı sonucuna ulaşılmıştır.

Uyumlu/olumlu tarzlardan biri olan üretici-sosyal mizah kullanıldığında öğretmenlerin stres yaşama düzeyi azalırken, alaycı, reddedici ve mizahi olmayan tarz kullanıldığında ise stres düzeyi artmaktadır. Üretici-sosyal mizahla stres arasında anlamlı bir fark bulunurken, mizahın diğer alt boyutları olan alayc1, onaylayıc1, reddedici ve mizahi olmayan tarz ise önemli bir etkiye sahip 
değildir. Üretici-sosyal mizahın stres yaşanmasında anlamlı bir yordayıcı olarak bulgulanması beklenilen bir sonuçtur. Literatürde olumlu olarak tanımlanan bir mizah türünün kullanılması hem kişilerarası etkileşimde hem de örgütsel anlamda etkileşimde istenilen bir durumdur. Stresin yaşandığı örgütlerde, yöneticilerin mizaha olumlu yaklaşmaları, mizahı takdir etmeleri ve mizah üretmeleri stresin neden olduğu birçok olumsuz durumun ortadan kaldırılmasında önemli bir rol oynamaktadır. Buna göre, yöneticilerin üretici-sosyal mizah gibi olumlu mizah tarzlarından birine sahip olması örgütlere birçok yönüyle olumlu katkı sağlayabilir. Bu yöneticiler okullarında işgörenlerin psikolojik anlamda yükünü hafifletebilir, stres yaşama düzeylerini azaltabilir ve iletişimi kuvvetlendirerek sağlıklı bir örgüt ikliminin tesis edilmesini sağlayabilir.

Araştırmaya katılan öğretmenlerin stres yaşama düzeylerinin cinsiyetlerine göre farklılaşıp farklılaşmadığına ilişkin bulgular incelendiğinde; cinsiyetin öğretmenlerin stres yaşama düzeyinin anlamlı bir belirleyicisi olduğu ortaya konulmuştur. Kadın öğretmenlerin algılarına göre okul yöneticilerinin alaycı mizahı daha fazla kullandıkları, erkek öğretmenlerin algılarına göre ise üreticisosyal mizahı daha fazla kullandıkları saptanmıştır. Kadın ve erkek öğretmenlerin okul yöneticilerinin sahip oldukları mizah tarzına ilişkin algıları farklılık göstermektedir. Okul yöneticilerinin mizah kullanma tarzları alaycı ve üretici-sosyal mizahta cinsiyete göre anlamlı bir fark ortaya çıkarılırken, onaylayıcı, reddedici, mizahi olmayan tarz da ise cinsiyete göre anlamlı bir farklılık bulunmamıştır. Cinsiyete göre anlamlı bir farklılığın olduğu araştırmanın bu bulgusu; daha önce yapılmış bazı araştırma sonuçları ile benzerlik gösterirken (Abel, 2002; Aydın, 1993; Erözkan, 2009; Erözkan ve Yılmaz, 2006; Sarı ve Aslan, 2005; Yerlikaya, 2009), cinsiyetin stres yaşama düzeyinin anlamlı bir belirleyicisi olmadığını ortaya koyan araştırma sonuçlarıyla (Kent, 1993; Koonce, 1997; Rahmani, 1994; Özdemir ve Recepoğlu, 2010; Recepoğlu ve Özdemir, 2012; Recepoğlu, 2011; Recepoğlu, 2015) farklılaşmaktadır. Bu farklılık; hedef grubunun özelliklerinden, örneklem grubunun farklı olmasından veya yapılan araştırmalarda ifade edilemeyen bazı değişkenlerden kaynaklanabilir. Kadın ve erkek öğretmenler arasındaki farkın her iki grubun doğuştan gelen yapısal özellikleri ve sosyo-kültürel özellikleri açısından, çevresindekileri algılama konusunda kadınların daha hassas ve duyarlı, erkeklerin ise daha çok dışadönük ilişkiler geliştirdikleri için olduğu öne sürülebilir.

Araştırmaya katılan öğretmenlerin stres yaşama düzeylerinin yaşa göre farklılaşıp farklılaşmadığına ilişkin bulgular incelendiğinde; yaşın öğretmenlerin stres yaşama düzeyinin anlamlı bir belirleyici olduğu ve öğretmenlerin yaşlarının arttıkça okul yöneticilerinin daha fazla alaycı mizah tarzını kullandıklarını algıladıkları sonucuna ulaşılmıştır. Araştırmanın bu bulgusu, bazı araştırma sonuçlarıyla örtüşürken (Recepoğlu, 2011; Recepoğlu ve Özdemir, 2012; Y1lmaz, 2011), yaşın öğretmenlerin stres yaşama düzeyinin anlamlı bir belirleyicisi olmadığını saptayan araştırma sonuçlarıyla (Kent, 1993; Koonce, 1997; Özdemir ve Recepoğlu, 2010; Recepoğlu, 2015; Vickers, 2004) benzerlik göstermemektedir. Alaycı mizahta yaşa göre anlamlı bir farklılık 
bulunurken, mizahın diğer alt boyutlarında ise yaşa göre anlamlı bir fark bulunmamıştır. Strese maruz kalma riskinin yaş ilerledikçe bireyin mizaha karşı tahammülünün azalıp negatif tutum takınmasından kaynaklandığı ileri sürülebilir.

Araştırmaya katılan öğretmenlerin stres yaşama düzeylerinin kıdeme göre farklılaşıp farklılaşmadığına ilişkin bulgular incelendiğinde; kıdemin öğretmenlerin stres yaşama düzeyinin anlamlı bir belirleyicisi olmadığı saptanmıştır. Bu bulgu, benzer araştırma bulgularıyla (Özdemir ve Recepoğlu, 2010; Recepoğlu, 2011; Recepoğlu ve Özdemir, 2012; Recepoğlu, 2015; Williams, 1994) paralellik gösterirken, Yılmaz’ın (2011) araştırma bulgularından farklılaşmaktadır.

Araştırmaya katılan öğretmenlerin stres yaşama düzeylerinin branşa göre farklılaşıp farklılaşmadığına ilişkin bulgular incelendiğinde; branşın öğretmenlerin stres yaşama düzeyinin anlamlı bir belirleyicisi olduğu ortaya konmuştur. Onaylayıcı mizah tarzında okul öncesi öğretmenlerinin branşları ile diğer öğretmenlerin görüşleri arasında anlamlı bir fark bulunurken, diğer mizah tarzları ve stres arasında anlamlı bir farklılık bulunamamışır. Bu bulgu, yapılan diğer çalışmalardan (Recepoğlu, 2011; Recepoğlu ve Özdemir, 2012) farklılaşmaktadır.

Araştırmaya katılan öğretmenlerin stres yaşama düzeylerinin medeni durumlarına göre farklılaşıp farklılaşmadığına ilişkin bulgular incelendiğinde; medeni durumun alaycı tarz ve reddedici tarzda stresin anlamlı bir belirleyicisi olduğu, öğretmenlerin medeni durumları ile mizahın diğer boyutları arasında ise anlamlı bir farklılaşmanın olmadığı ortaya konmuştur. Dul veya boşanmış öğretmenlerin, okul yöneticilerinin alaycı ve reddedici mizah tarzlarını kullandıklarını ileri sürmeleri ve stresin anlamlı bir yordayıcısı olarak bulgulanması beklenilen bir durumdur. Sürekli değişen durumlar, örgütsel yaşamda karşılaşılan sorunlar, boşanma veya eşin kaybı ile biten evlilikler ve özel hayattaki sorunlar öğretmenlerin örgütsel yaşamda da stresi daha fazla algılamalarına neden olabilir.

Araştırmaya katılan öğretmenlerin stres yaşama düzeylerinin mesleklerini sevme durumlarına göre farklılaşıp farklılaşmadığına ilişkin bulgular incelendiğinde; öğretmenlerin mesleklerini sevme durumlarında reddedici mizah tarzının stres yaşamlarının anlamlı bir belirleyicisi olduğu ortaya konmuştur. Öğretmenlerin mesleğini sevme durumlarının mizahın diğer boyutları olan alaycı, üretici-sosyal, onaylayıcı ve mizahi olmayan tarz ile stres üzerinde etkili bir rol oynamadığı saptanmıştır. Araştırmanın bu bulgusu, mesleğini orta düzeyde seven öğretmenlerin okul yöneticilerinin daha fazla reddedici mizah tarzını kullandıklarını ileri sürmeleri beklenilen bir sonuç değildir. Mesleğini orta düzeyde seven öğretmenlerin, okul yöneticilerinin olumlu mizah türlerinden birine daha yakın olduklarını ifade etmeleri beklenilen bir sonuçtur.

Araştırmaya katılan öğretmenlerin stres yaşama düzeylerinin sosyo-ekonomik durumlarına göre farklılaşıp farklılaşmadığına ilişkin bulgular incelendiğinde; sosyo-ekonomik durumun öğretmenlerin stres yaşama düzeylerinin anlamlı bir belirleyicisi olmadığı sonucuna ulaşılmıştır. Bu bulgu, bazı çalışmaların sonuçları ile benzerlik göstermektedir (Erözkan, 2009). Okulda yaşanan 
olumlu-olumsuz durumlar herhangi bir gelir düzeyine sahip öğretmenleri aynı şekilde etkileyebilir. Örneklemi oluşturan öğretmenlerin mizah tarzlarını algılama konusunda sosyo-ekonomik düzeylerinin strese ilişkin etkin bir rol oynamadığı düşünülebilir.

Araştırmaya katılan öğretmenlerin stres yaşama düzeylerinin mesleği bırakma durumlarına göre farklılaşıp farklılaşmadığına ilişkin bulgular incelendiğinde; mesleği bırakmayı düşünen öğretmenler okul yöneticilerinin daha fazla alaycı ve reddedici mizahı kullandıklarını ifade etmektedir. Alaycı ve reddedici mizah tarzlarının stresin anlamlı bir belirleyicisi olduğu sonucu ortaya konmuştur. Öğretmenliği bırakmayı düşünen öğretmenlerin okul yöneticilerinin daha çok alaycı ve reddedici gibi olumsuz mizah türlerini kullandıklarını ifade etmeleri ve öğretmenlerin strese maruz kalmaları beklenilen bir sonuçtur. Okul yöneticilerinin mizaha karşı negatif bir tutum içeren alaycı ve reddedici mizahı benimsemeleri okullarındaki öğretmenlerin, diğer çalışanların, öğrencilerin ve velilerin stres yaşamalarına neden olabilir.

Öğrenmenin, gelişmenin ve istendik sonuçların gerçekleşmesi beklenilen eğitim örgütlerinde, okul yöneticilerinin etkili bir lider olabilmeleri, okullarında sağlkklı bir iklimin gelişmesini sağlamaları, stres kaynaklarının ortadan kaldırılması ve stresin olumsuz etkilerinin en aza indirilmesi için olumlu mizah tarzlarını kullanmaları istenilen bir durumdur.

Sonuç olarak, okul yöneticilerinin çok fazla mizah kullanmadıkları, alaycı ve reddedici mizah kullandıklarında öğretmenlerin strese girdikleri, farklı demografik özelliklere sahip olan öğretmenlerin mizah davranışlarını farklı algıladıkları ortaya çıkmıştır. Bu araştırma sonrasında, literatürde mizah ve algılanan stresin birlikte incelendiği çalışmaların olmayışı veya çok az oluşu, benzer araştırmaların eğitim ve öğrenim gerçekleştirildiği okulların her eğitim kademesinde veya daha genel anlamda hiyerarşik düzenin bulunduğu her örgütte, farklı hedef kitleleri kapsayacak şekilde incelenmesinin alana/alan dışına katkısının olacağı düşünülmektedir. İlkokul yöneticilerinin olumlu bir kişilik özeliği olan mizahı etkili kullanabilmeleri durumunda öğretmenlerin stres yaşamaları azalacak ve eğitim örgütlerinde yaşanılan sorunlar daha kolay çözülebilecektir.

\section{KAYNAKÇA}

Abel, M. H. (1998). Interaction between humor and gender in moderating relationships, stress and outcomes. Journal of Psychology: Interdisciplinary and Applied, 132 (3), 267-276.

Abel, M. H. (2002). Humor, stress, and coping strategies. Humor: International Journal of Humor Research, 15 (4), 365-381.

Aslan, H. (2006). Ortaöğretim kurumlarında görev yapan öğretmenlerin öğrenilmiş güçlülük düzeyleri ve cinsiyetlerine göre mizah tarzlarının incelenmesi (Yüksek Lisans Tezi), Çukurova Üniversitesi, Sosyal Bilimler Enstitüsü, Adana. 
Aydın, G. (1993, Eylül). İç-dış kontrol odağı inancı ile durumluk mizah tepkisi arasındaki ilişki. II. Ulusal Psikolojik Danışma ve Rehberlik Kongresinde sunulmuş bildiri. Hacettepe Üniversitesi, Ankara.

Aydın, İ. (2008). İş yaşamında stres. Ankara: Pegem A.

Aydın, Ş. (2004). Örgütsel stres yönetimi. Dokuz Eylül Üniversitesi Sosyal Bilimler Enstitüsü Dergisi, 3 (6).

Babad, E. Y. (1974). A multi-method approach to the assessment of humor: A critical look at humor tests. Journal of Personality, 42, 618-632.

Balcı, A. (2000). Öğretim elemanlarının işs stresi. Kuram ve uygulama. Ankara: Nobel Akademik Yayıncilik.

Baltaş, Z. \& Baltaş, A. (2008). Stres ve başa çıkma yolları. İstanbul: Remzi Kitabevi.

Barth, R. S. (1990). A personal vision of a good school. Phi Delta Kappan, 71, 512-516.

Blase, J. P. (1984). A data based model of how teachers cope with work stress. Journal of Educational Administration, 12, 173-191.

Blase, J. P., Dedrick, C., \& Strathe, M. (1986). Leadership behavior of school principals in relation to teacher stress, satisfaction, and performance. Journal of Humanistic Education and Development, 24, 159-171.

Braham, B. J. (1998). Stres yönetimi. Ateşaltında sakin kalabilmek (V.G. Diker, Çev.). İstanbul: Hayat.

Büyüköztürk, Ş., Çakmak, E. K., Akgün, Ö. E., Karadeniz, Ş., \& Demirel, F. (2011). Bilimsel araştırma yöntemleri. Ankara: Pegem.

Cemaloğlu, N. (2017). Mutlu okulun sihirli anahtart. https://www.byegiteam.com/singlepost/2017/04/20/Mutlu-Okulun-Sihirli-Anahtar\%C4\%B1 sayfasından erişilmiştir.

Cemaloğlu, N., Kalkan, F., Dağlı, E. \& Çilek, A. (2014). Examining the relation between humor acts of school principals and teachers' exposure level to mobbing and organizational cynicism based on the perceptions of teachers. International Journal of Teaching and Education, 2 (1), 2-17.

Cemaloğlu, N., Recepoğlu, E., Şahin, F., Daşçı, E. \& Köktürk, O. (2012). Mizah davranışları ölçeğinin geliştirilmesi: geçerlik ve güvenirlik çalışması. Türk Eğitim Bilimleri Dergisi, 10(4), 694-716.

Chapman, A. J., \& H. C. Foot (Eds.). (1996). Humor and laughter: Theory, research, and applications. New Brunswick: NJ, Transaction.

Cohen, S., Kamarck, T., \& Mermelstein, R. (1983). A global measure of perceived stress. Journal of Health and Social Behavior, 24, 385-396. 
Cüceloğlu, D. (1994). İnsan ve davranışı. Psikolojinin temel kavramları. İstanbul: Remzi Kitabevi.

Çetinkaya, F. F. \& Şener, E. (2016). Yöneticilerin mizah tarzlarının çalışanların örgütsel sinizm algisına etkisi. Journal of Business Research Turk, 8(3), 207-221.

Çevik A., \& Şentürk V. (2008) Tarihsel süreçte psikosomatik tıp ve psikosomatik bozukluklara genel bir bakış. Türkiye Klinikleri Psikiyatri Dergisi, 1, 1-11.

DeFrank, R. S., \& Ivancevich, J. M. (1998). Stress on the job: An executive update. The Academy of Management Executive, 12 (3), 55-66.

Dick, R. V., \& Wagner, U. (2001). Stress and strain in teaching: A structural equation approach. British Journal of Educational Psychology, 71, 243-259.

Doğan, F. (2008). Sinıföğretmenlerinin stres kaynakları ve baş etme yoları (Kilis ili örneği). (Yüksek Lisans Tezi), Gazi Üniversitesi Eğitim Bilimleri Enstitüsü, Ankara.

du Pre, A. (1998). Humor and the healing arts: a multimethod analysis of humor use in health care. Mahwah, NJ: Lawrence Erlbaum.

Durna, U. (2006). Üniversite Öğrencilerinin Stres Düzeylerinin Bazı Değişkenler Açısından İncelenmesi. Atatürk Üniversitesi İktisadi ve İdari Bilimler Fakültesi Dergisi, 20 (1), 319343.

Erickson, S. J., \& Feldstein, S. W. (2007). Adolescent humor and its relationship to coping, defense strategies, psychological distress and well-being. Child Psychiatry and Human Development, 37 (3) 255-271.

Erözkan, A. (2009). Üniversite öğrencilerinin kişiler arası ilişki arası ilişki tarzları ve mizah tarzları. Dokuz Eylül Üniversitesi Buca Eğitim Fakültesi Dergisi 26, 56-66.

Erözkan, A. ve Yılmaz, B. (2006, Eylül). Üniversite ögrencilerinin mizah tarzları ve bağlanma stilleri. XV. Ulusal Eğitim Bilimleri Kongresinde sunulmuş bildiri. Muğla Üniversitesi, Muğla.

Ertekin, Y. (1993). Stres ve yönetim. Ankara: TODAİE.

Gibson, J. L., Ivanchevich, J. M., Donelly, J. H. \& Konopaske, R. (2012). Organizations: Behavior, structure, processes (14th Ed.). New York: McGraw.

Goldberger, L. \& Breznitz, S. (Eds). (1982) . Handbook of stress. NY: The Free.

Güçlü, N (2001). Stres yönetimi. Gazi Üniversitesi Eğitim Fakültesi Dergisi 21(1), 91-109.

Hallinger, P. and Murphy, J. (1986). The social context of effective schools. American Journal of Education, 94 (5), 328-355.

Hampes, W. P. (1992). Relation between intimacy and humor. Psychological Reports, 71(1), 127130. 
Hampes, W. P. (2010). The relation between humor styles and empathy. Europe's Journal of Psychology, 6(3), 34-45.

Hannigan, B., Edwards, D., \& Burnard, P. (2004). Stress and stress management in clinical psychology: findings from a systematic review. Journal of Mental Health, 13(3), 236 -245.

Hargreaves, G. (1999). Stresle baş etmek. (A. C. Akkoyunlu, Çev.). İstanbul: Doğan.

Hurren, B. L. (2001). The effects of principals' humor on teacher's job satisfaction (Doctoral dissertation). Retrieved from ProQuest Dissertations and Theses database. (UMI No. 3042753)

Işıkhan, V. (2004). Çalışma hayatında stres ve başa çıkma yolları. Ankara: Sandal.

Ivancevich, J. M. \& Matteson, M.T. (1990). Organizational behavior and management (2nd Edition). Boston, MA: Irwin McGraw-Hill.

Karasar, N. (2008). Bilimsel araştırma yöntemi. Ankara: Nobel Akademik Yayıncılık.

Kaya, M. D. \& Keskin, G. (2008). Yöneticilerin yönetsel stres kaynakları ve strese yatkınlık düzeyleri: Erzurum'da bir araştırma. Atatürk Üniversitesi Sosyal Bilimler Enstitüsü Dergisi, 11(1), 371 - 388 .

Kent, S. H. (1993). An investigation of the relationship between humor style and effectiveness of elementary school principals as perceived by teachers in Georgia. (Doctoral dissertation). Retrieved from ProQuest Dissertations and Theses database. (UMI No. 9416267)

Koonce, W. J. (1997). The relationship between principals'humor styles and school climate in elementary schools (Doctoral dissertation). Retrieved from ProQuest Dissertations and Theses database. (UMI No. 9731494)

Kuiper, N. A \& Martin, R. A. (1998). Is sense of humor a positive personality characteristic. In Ruch, W. (Ed.), The sense of humor: Explorations of a personality characteristic (159-178). New York: Mouton de Gruyter.

Kuiper, N. A., Grimshaw, M., Leite, C., \& Kirsh, G. (2004). Humor is not always the best medicine: Specific components of sense of humor and psychological well-being. Humor: International Journal of Humor Research, 17 (1-2), 135-168.

Kuiper, N. A., Martin, R. A., \& Olinger, L. J. (1993). Coping humour, stress, and cognitive appraisals. Canadian Journal of Behavioural Science, 25, 81-96. http://dx.doi.org/10.1037/h0078791

Kyriacou, C. (2001). Teacher stress: Directions for future research. Educational Review, 53(1), $27-$ 35.

Lazarus, R. S. (1966). Psychological stress and the coping process. New York: Mc Graw-Hill.

Lazarus, R. S., \& Folkman, S. (1984). Stress, appraisal and coping. New York, NY: Springer. 
Litt, M. D., \& Turk, D. C. (1985). Sources of stress and dissatisfaction in experienced high school teachers, Journal of Educational Research, 78(3), 178-185.

Lowe, J. (1986) Theories of ethnic humor: How to enter, laughing. American Quarterly, 38(3) 438460.

Magnuson, J. (1990). Stress management. Journal of Property Management, 55(3), 24-26.

Martin, R. A. \& Lefcourt, H. M. (1983). Sense of humor as a moderator of the relation between stressors and moods. Journal of Personality and Social Psychology, 45,1313-1324.

Martin, R. A. (1996). Humor as therapeutic play: Stress-moderating effects of sense of humor. Journal of Leisurability, 23(4), 8-15.

Martin, R. A. (1998). Approaches to the sense of humor: A historical view. W. Ruch (Ed.), Sense of humor. New York: Mouton de Gruyter.

Martin, R. A. (2001). Humor, laughter, and physical health: Methodological issues and research findings. Psychological Bulletin, 127, 504-519.

Martin, R. A. (2007). The psychology of humor: An integrative approach. San Diego, CA: Elsevier.

Martin, R. A., Puhlik-Doris, P. Larsen, G., Gray, J. \& Weir, K. (2003). Individual differences of uses of humor and their relation to psychological wellbeing: Development of the humor styles questionnaire. Journal of Research in Personality, 37, 48-75.

Mauriello, M. \& McConatha, J.T. (2007). Relations of humor with perception of stress. Psychological Reports, 101, 1057-1066.

Mertz, D. J. C. (2000). Teachers' perceptions of principals' humor style: Its effect on teacher satisfaction and burnout. (Doctoral dissertation). Retrieved from ProQuest Dissertations and Theses database. (UMI No. 9991715)

Napier, R., \& Gershenfeld, M. (1981). Groups: theory and experience. Boston: Houghton Mifflin.

Özdemir, A. (2002). Okul yöneticiliğinde mizahi yaklaşım. Türkiye Sosyal Araştırmalar Dergisi, 6(3), 49-61.

Özdemir, S. \& Recepoğlu, E. (2010, Mayıs). Örgütsel sağlık ve mizah. V. Ulusal Eğitim Yönetimi Kongresi, Antalya, 219-229. Ankara: Nobel

Özdemir, S., Sezgin, F., Kaya, Z. \& Recepoğlu, E. (2011). The relationship between primary school teachers' coping styles with stress and humor styles. Educational Administration: Theory and Practice, 17(3), 405-428.

Özenç, S. (1998). Algllanan anne - baba tutumlarının durumluk mizah tepki düzeyine etkisi. (Yüksek Lisans Tezi), Ondokuz Mayıs Üniversitesi Sosyal Bilimler Enstitüsü, Samsun. 
Öztürk, N. (1995). İlkokul öğretmenlerinin çalıştıkları okulun iklimine ilişkin algıları ile gerilim (stres) düzeyleri arasındaki ilişkiler (İzmir örneği) (Yüksek Lisans Tezi), Dokuz Eylül Üniversitesi Eğitim Bilimleri Enstitüsü, İzmir.

Özünlü, Ü. (1999). Gülmecenin dilleri. Ankara: Doruk.

Pehlivan, İ. (1995). Yönetimde stres kaynakları. Ankara: Pegem.

Philbrick, K. T. (1989). The use of humor and effective leadership styles. Doctoral dissertation. Retrieved from ProQuest Dissertations and Theses database. (UMI No. 9021898)

Phillips, K. A. (2000). The use of humor and effective leadership styles by elementary principals in central florida (Doctoral dissertation). Retrieved from ProQuest Dissertations and Theses database. (UMI No.9977824)

Porterfield, A. (1987). Does sense of humor moderate the impact of life stress on psychological and physical weell-being. Journal of Research in Personality, 21, 306-307.

Puderbaugh, A. (2006). The relationship between supervisor's humor styles and subordinate job satisfaction. (Doctoral dissertation). Retrieved from ProQuest Dissertations and Theses database. (UMI No. 3208068)

Rahmani, L. (1994). Humor styles and managerial effectiveness. (Doctoral dissertation, University of LaVerne, 1992). Dissertation Abstracts International, 55 (5), 1161.

Recepoğlu E. (2008). Okul müdürlerinin mizah yeteneğinin öğretmenlerin iş doyumlarına etkisi. Eğitim ve Bilim, 33 (150), 74-86.

Recepoğlu, E. \& Özdemir, S. (2012). Okul müdürlerinin mizah tarzları ile öğretim liderliği davranışları arasındaki ilişki. İnönü Üniversitesi Ĕgitim Fakültesi Dergisi, 13(3), 23-42.

Recepoğlu, E. (2011). Öğretmen algllarına göre okul müdürlerinin mizah tarzlart ile öğretim liderliği davranışları ve okulun örgütsel sağlı̆̆ı arasındaki ilişski (Doktora Tezi), Gazi Üniversitesi Eğitim Bilimleri Enstitüsü, Ankara.

Recepoğlu, E. (2015). Liselerde görev yapan okul müdürlerinin mizah tarzı ile öğretim liderliği davranışları arasındaki ilişkinin incelenmesi. Cumhuriyet International Journal of Education, 4 (3), 31-46.

Rojas, V. M. \& Kleiner, B. H. (2000). The art and science of effective stress management. Management Research News, 23 (7/8), 103-106.

Romero, E. J., \& Arendt, L. A. (2011). Variable effects of humor styles on organizational outcomes. Psychological Reports, 108 (2), 649-659.

Rowshan, A. (2003). Stres yönetimi (Ş. Cüceloğlu, Çev.). İstanbul: Sistem.

Sala, F. (2003). Laughing all the way to the bank. Harvard Business Review, 81 (9), 16-17.

Sand1kc1, E. (2010). Stresin tükenmişlik boyutları üzerindeki etkisi: Diyarbakır'da öğretmenler üzerinde bir araştırma (Yüksek Lisans Tezi), Erciyes Üniversitesi Eğitim Bilimleri Enstitüsü, Kayseri. 
Sarı, T. ve Aslan, H. (2005). Mizah tarzları ve başaçıkma stratejileri arasındaki ilişki. VIII. Ulusal Psikolojik Danışma ve Rehberlik Kongresi, Marmara Üniversitesi, İstanbul.

Saroglou, V., \& Scariot, C. (2002). Humor styles questionnaire: Personality and educational correlates in Belgian high school and college students. European Journal of Personality, 16,43-54.

Schermerhorn, Jr., J.R., Hunt, J.G., \& Osborn, R.N. (1988). Managing Organizational Behavior (3rd Edition). New York: John Wiley \& Sons.

Shors T. J. (2006) Stressful experience and learning across the lifespan. Annual Review of Psychology, 57, 55-85.

Sosyal, A. (2009). Farklı sektörlerde çalışan işgörenlerde örgütsel stres kaynakları: Kahramanmaraş ve Gaziantep’te bir araştırma. Süleyman Demirel Üniversitesi, İIBF Dergisi, 14 (2), 333-359.

Spurgeon, K. (1998). Humor versus burnout: An organizational anaylsis of principals and teachers. (Doctoral dissertation). Retrieved from ProQuest Dissertations and Theses database. (UMI No. 9831984)

Taylor, S.E. (2003). Health psychology. NewYork: McGraw-Hill.

Thorson, J. A. \& Powell, F. C. (1991). Measurement of sense of humor. Psychological Reports, 69, 691-702.

Thorson, J. A. \& Powell, F. C. (1993). Development and validation of a multidimensional sense of humor scale. Journal of Clinical Psychology, 49 (1), 13-23.

Tümkaya, S. (2007). Burnout and humor relationship among university lecturers. Humor: International Journal of Humor Research, 20(1), 73-92. doi:10.1515/HUMOR.2007.004

Vickers, P. C. (2004). The use of humor as a leadership tool by Florida public school principals (Doctoral dissertation). Retrieved from ProQuest Dissertations and Theses database. (UMI No. 3144895).

Williams, R. A. \& Clouse, R. W. (1991). Humor as a management technique: Its impact on school culture and climate (Report No. EA 023 388). http://www.eric.ed.gov/PDFS/ED337866.pdf adresinden erişilmiştir.

Williams, R. A. (1994). The perceived value of administrator humor to school climate (Doctoral dissertation). Retrieved from ProQuest Dissertations and Theses database. (UMI No. 9429737)

Yang, X., Ge, C., Hu, B., Chi, T., \& Wang, L. (2009). Relationship between quality of life and occupational stress among teachers. Public Health, 123 (11), 750-755.

Yates, E. (1986). Gerilim altında yönetici. (F. Dilber, Çev.). İstanbul: İlgi.

Yerlikaya, E. (2003). Mizah Tarzları Ölçeğinin uyarlama çalışması. Yüksek Lisans Tezi, Çukurova Üniversitesi Sosyal Bilimler Enstitüsü, Adana. 
Yerlikaya, E. (2009). Üniversite öğrencilerinin mizah tarzlar ile algılanan stres, kaygı ve depresyon düzeyleri arasındaki ilişkinin incelenmesi ( Doktora Tezi), Çukurova Üniversitesi Sosyal Bilimler Enstitüsü, Adana.

Yerlikaya, N. (2007). Lise öğrencilerinin mizah tarzları ile stresle başa çıkma tarzları arasındaki ilişkinin incelenmesi (Yüksek Lisans Tezi), Çukurova Üniversitesi Sosyal Bilimler Enstitüsü, Adana.

Yıldırım, İ. (1991). Stres ve stresle başa çıkmada gevşeme teknikleri. Hacettepe Üniversitesi Eğitim Fakültesi Dergisi, 6, 175-189.

Yılmaz, A. \& Ekici, S. (2003). Örgürsel yaşamda stresin kamu çalışanlarının performansına etkileri üzerine bir araştırma. Celal Bayar Üniversitesi İ̈BF Yönetim ve Ekonomi Dergisi 10 (2), 119.

Yılmaz, K. (2011). Okul yöneticilerinin mizah tarzlarının çeşitli değişkenler açısından incelenmesi. İnönü Üniversitesi Eğitim Fakültesi Dergisi, 12(1), 27-44

Yip, J. A. \& Martin, R. A. (2006). Sense of humor, emotional intelligence, and social competence. Journal of Research in Personality, 40, 1202-1208.

Ziegler, V. and Boardman, G. (1986). Humor: the seventh sense in leadership. National Forum of Educational Administration and Supervision, 2 (2), 11-15.

Ziegler, V., Boardman, G., \& Thomas, M. D. (1985). Humor, leadership, and school climate. The Clearing House, 58, 346-348.

\section{Extended Abstract}

Many problems in educational organizations may cause stressful environment and thus affect teachers' capacity to accomplish their duties effectively. Stress threatens human health, reduces productivity and causes many negative effects on a person. Humor has started to be used as a tool in coping with stress. That is why humor has become an important subject in recent years. Many findings show that having positive sense of humor is very beneficial to physical and psychological health. Humor develops interpersonal relations and diminishes stress and anxiety. It is believed that there is a link between humor and psychological well-being. Humor also promotes such actions as building group adherence, increasing job satisfaction, contributing to productivity and enhancing leadership effectiveness. Nowadays, the teachers who work in primary schools also face some emotional troubles due to various stress sources. There are a few studies concerned with the relationships between humor styles of primary school administrators and their coping styles with stress.

Therefore, humor which is treated as positive organizational behavior is one of the basic variables of this survey. Although lots of studies have been conducted about stress, which is another variable of this survey will try to determine whether there is a relationship between school administrators' humor style and teachers' percieved stress level. Moreover, the effect of the humor styles used by administrators on the teachers perceieved stress will also be introduced. 
The aim of this study is to determine the relationship between primary school administrators' humor styles and teachers' percieved stress level, and the examination of this relationship according to some variables. This research is conducted with relational screening model. The research model consists of two variables in total which are an independent/external variable (the humor styles of school administrators) and an dependent/internal variable (the the stress level of teachers). However, other independent/external variables consist of teachers' gender, age, branch, seniority and socio-economic level. The population of the research includes 1636 teachers who work at 75 state primary schools at three different socio-economic levels (low, medium, high) of Çankaya district of Ankara. Multi-stage sampling method has been used in order to determine the sample from the population. At the first stage, stratified sampling method has been used and at the second stage, simple random sampling method has been used. 311 teachers who work at 30 different schools of Çankaya district have been reached. A questionnaire which includes two different data collection tools is given to these 311 teachers. 11 of the questionnaires are filled inappropriately, so, they have been left out. As the data collection tool, Humor Behavior Scale (HBS) and Percieved Stress Scale have been utilized. HBS was developed by Cemaloğlu, Recepoğlu, Şahin, Daşçı and Köktürk in 2012. HBS consists of 30 items in total; these items constitute 5 subdimensions; and these subdimensions are cynical, productive-social, approving, rejectionist and non-humorous style. Percieved Stress Scale was adapted by Yerlikaya in 2003. This scale consists of 14 items. For the analysis of the collected data, SPSS 24.0 has been used. The findings of the research show that school administrators exhibit low-level of humor and they are more likely to perform midlevel of approving humor style rather than the other styles. They prefer humor style mostly from subdimensions of humor which is approving style, and they also prefer cynical styles to the others. The results show that producing-social humor style is a predictor on percieved stress level while other subdimensions have no meaningful relationship with stress. Moreover, as long as primary school adminitrators exhibit more cynical and rejectionist humor style, teachers' percieved stress level increases, and as they exhibit more approving humor styles, teachers' percieved stress level decreases. According to the results of the research, it is suggested that school administrators should be motivated to use humor styles effectively through training, seminars and conferences in order not to experience undesirable cases in the schools and in order to enhance the awareness of the effect of humor on teachers' percieved stress level. 